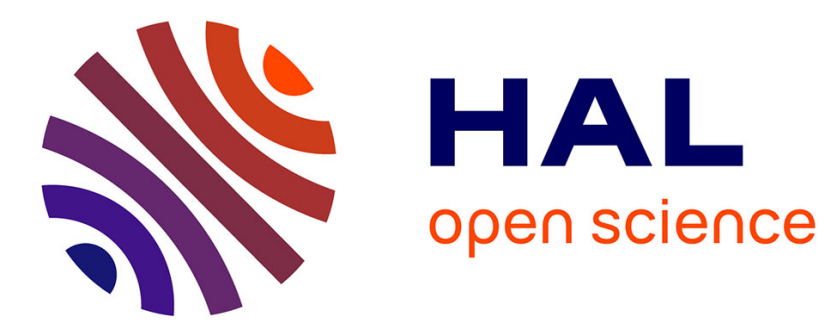

\title{
Bank Capital and Self-Interested Managers: Evidence from Indonesia
}

Wahyoe Soedarmono, Philippe Rous, Amine Tarazi

\section{To cite this version:}

Wahyoe Soedarmono, Philippe Rous, Amine Tarazi. Bank Capital and Self-Interested Managers: Evidence from Indonesia. 2011. hal-00918584

\section{HAL Id: hal-00918584 \\ https://hal-unilim.archives-ouvertes.fr/hal-00918584}

Preprint submitted on 16 Dec 2013

HAL is a multi-disciplinary open access archive for the deposit and dissemination of scientific research documents, whether they are published or not. The documents may come from teaching and research institutions in France or abroad, or from public or private research centers.
L'archive ouverte pluridisciplinaire HAL, est destinée au dépôt et à la diffusion de documents scientifiques de niveau recherche, publiés ou non, émanant des établissements d'enseignement et de recherche français ou étrangers, des laboratoires publics ou privés. 


\title{
Bank Capital and Self-Interested Managers: Evidence from Indonesia
}

\author{
Wahyoe Soedarmono ${ }^{1}$, Philippe Rous, Amine Tarazi \\ Université de Limoges, LAPE, 5 rue Félix Eboué, BP. 3127, 87031 Limoges, France
}

\section{This version: July 2011 \\ Do not quote}

\begin{abstract}
The aim of this paper is to analyze the relationship between capital ratios, the cost of intermediation and risk taking in banking by considering the presence of self-interested managers. To our knowledge such problems have never been taken into consideration in the empirical literature on the link between bank capital and risk. Using a simultaneous equations model applied to monthly data over the 2004-2007 period for 99 Indonesian commercial banks, we find that a higher capital ratio is associated with an increase in the cost of intermediation and a decrease in risk and profitability. Hence, there is a strong presumption that managers might be driving banks to become safer but less profitable since more risky but also more profitable loans could be bypassed. Moreover, our results show that domestic private-owned banks are more likely to suffer from a managerial self-interest problem than state-owned banks, joint-venture banks, and foreign-owned banks. Our findings support the call for the implementation of the ownership consolidation policy to enhance shareholders' domination in Indonesian banks, notably in private-owned banks.
\end{abstract}

JEL Classification : G21, G28,

Keywords: Bank Capital, Bank Risk, Managerial Self-Interest, Ownership Consolidation, Indonesia

\footnotetext{
${ }^{1}$ Corresponding author.

Email: wahyoe.soedarmono@unilim.fr, philippe.rous@unilim.fr, amine.tarazi@unilim.fr
} 


\section{Introduction}

In spite of a growing literature analyzing the link between capital requirements and bank risk, no consensus has been reached on the sign of the relationship between both dimensions. Both theoretical and empirical papers, ranging from portfolio theory-based approaches (Kahane, 1977; Koehn and Santomero, 1980; Kim and Santomero, 1988) to incentive-based approaches (Besanko and Kanatas, 1996; Blum, 1999; Milne, 2002; Blum, 2003; Jeitschko and Jeung, 2005) remain inconclusive.

In the context where a bank acts as a portfolio manager, higher capital requirements will directly alter the bank's leverage ratio. As a consequence, the bank will reshuffle its portfolio by selecting riskier assets (loans) to maintain its expected return on equity at an optimal level (Kahane, 1977; Koehn and Santomero, 1980). However, building on the same portfolio selection framework, Milne (2002) argues that this literature fails to "treat banks as forward looking optimizers balancing the benefits of their lending decisions against the cost of regulatory breach", where such behaviours depend on how shareholders and bankers manage banks' capital adequacy ratios and loan porfolios.

In line with this view, Bris and Cantale (2004) consider that the previous literature on bank capital requirements only views the bank as a whole and hence fails to consider agency conflicts among shareholders and bankers (managers). Moreover, Hughes and Mestler (1994) explicitly highlight that bank managers are not maximizing shareholders' value. While such agency conflicts are widely explored in the corporate finance literature, only a few papers deal with this issue regarding banking firms.

Gorton and Rosen (1995) are the first to model banks' portfolio management and internal agency conflicts to explain the continuous decline in U.S. banks' profitability during the 1980s. In their model, there are two types of managers who have private benefit to control, namely "good" managers and "bad" managers. In facing declining investment opportunities in the U.S. market, the good managers choose either "profitable" risky loans or "profitable" safe loans, while the bad managers choose either "unprofitable" risky loans (excessive risk taking) or "unprofitable" safe loans (excessive entrenchment). When banks have a large proportion of bad managers and bank shareholders can only imperfectly control them, the aggregate risk taking may be excessive, as long as deposit insurance exists and capital requirements are easily satisfied. Since their model does not consider the role played by the regulator to discipline banks' behaviour, there is no explicit external agency conflict between the banks' shareholders and the regulator. 
Gorton and Rosen (1995) also show that such managerial entrenchment to take on excessive risk is due to the incentives that managers face when the fraction of the bank they own is large enough for them to make outside discipline costly, but not large enough for their interests to be aligned with those of outsiders. They further establish conditions in which the relationship between managerial ownership and risk taking can take the form of an inverse Ushape curve.

Jeitschko and Jeung (2005) build a model of banks' portfolio management where external agency conflicts (regulator-shareholder) exist and moral hazard can be constrained by the regulator's action. In their model, the regulator, bank shareholders and the manager have different "domination power" on bank portfolios. If the regulator (or the deposit insurance company) dominates, its objective is to minimize the option value of deposit insurance, i.e. bank default risk, which can only be achieved under a high level of the capital adequacy ratio. If shareholders dominate, their objective is to choose risk-taking strategies that maximize the expected value of bank equity. But if managers dominate, their objective is to manage risk to maximize the expected value of their private benefits of control. However, the impact of such managerial behaviour on bank default risk remains unclear.

Sullivan and Spong (2007) empirically highlight that managerial stock ownership boosts risk-taking strategies indicating that hired managers are more likely to have incentives in line with those of shareholders. However, Saunders et al. (1990) find that "entrenchedmanager-controlled" banks are less risky than "shareholder-controlled" banks during the 1979-1982 period of relative deregulation. Some papers also find U-shaped relationships between managerial ownership and bank risk taking, which is also due to managerial entrenchments (Chen et al., 1998; Anderson et al., 2000). To deal with managerial entrenchments, John et al. (2000) are the first to build a theoretical model analyzing the optimal package of managerial compensation under capital requirement rules and deposit insurance. Unfortunately, in their model, regulation does not play any role regarding managerial entrenchments and, thus, it is somehow irrelevant.

Extending Saunders et al. (1990) and John et al. (2000), Bris and Cantale (2004) build a theoretical model that analyzes the implications of capital requirements on managerial selfinterest and bank risk taking. Under asymmetric information between shareholders and managers, a higher capital requirement will drive self-interested managers to monitor bank loan portfolios and comply with the new requirement (increase the capital adequacy ratio). Self-interested managers will follow such a strategy to maximize their compensation, since bank failure or a decline in the capital adequacy ratio will lower managerial compensation. As 
a consequence, to preserve their compensation, managers might target safer loan portfolios at the cost of an increase in inefficiency due to excessive monitoring costs. Hence, banks might become too safe and less profitable because more socially desirable risky loans (but also more profitable) are possibly bypassed. In this setting, bank shareholders should provide managers with a better compensation package that is compatible with managerial efforts in producing socially desirable risky loans to maintain shareholders' profitability. The optimum compensation package should be negatively related to the capital adequacy ratio and positively linked to risk taking.

In parallel, empirical papers on capital requirements mainly analyze the problem of bank capitalization and its impact on risk and profitability, without taking into account agency conflicts between shareholders and managers (see for example, Aggarwal and Jacques (2001), Rime (2001), Bischel and Blum (2004), Lin et al. (2005), Murinde (2006)). An exception is Altunbas et al. (2007) and Laeven and Levine (2009) who provide evidence which is somehow close to our objective in examining the managerial self-interest problem. In the case of European banks during the period 1992-2000, Altunbas et al. (2007) report that banks with more capital tend to be less efficient; but they also tend to take on excessive risk. Hence, there is no evidence that bank capital raises the managerial self-interest problems that drive bank portfolios to become safer but less profitable. Laeven and Levine (2009) analyze a large sample of 288 banks from 48 countries during the 1996-2001 period and show that capital requirements and more stringent bank activity restrictions are associated with higher risk in banks having a sufficiently powerful shareholder, but the opposite is true in widely-held banks when shareholders' domination is relatively weak. However, their work does not explicitly consider domination by self-interested managers which probably occurs in widelyheld banks with weaker shareholders and that might boost the bank's safety and inefficiency at the same time.

To our best knowledge, there has been no attempt to empirically analyze the presence of self-interested managers through the link between bank capital ratios and risk taking. The present paper aims to fulfil this gap. To assess these predictions, we focus on the Indonesian banking industry, where capitalization, governance and ownership have become major policy issues in the aftermath of the 1997 crisis (Pangestu, 2003). We work on monthly data for 99 commercial banks with four different ownership types (state-owned, private-owned, joint- 
venture, and foreign-owned bank). Our study covers the 2004-2007 period when strict regulations were introduced on bank capital in Indonesia ${ }^{2}$.

Our approach to assess this issue is related to Altunbas et al. (2007), Laeven and Levine (2009) and also, more generally, to the broad literature on bank ownership structure and risk taking (Saunders et al., 1990; Sullivan and Spong, 2007). However, instead of separating banks into two groups ("shareholder-controlled banks" and "manager-controlled banks") we capture the managerial domination problem by building on the work of Naceur and Kandil (2009) and Demirgüc-Kunt et al. (2004). Naceur and Kandil (2009) study the impact of capital requirements on the cost of intermediation and profitability in Egyptian banks during 1989-2004 ${ }^{3}$, while Demirgüc-Kunt et al. (2004) emphasize the use of the cost of intermediation and overhead costs to tackle bank inefficiency issues.

Because we use monthly data for a relatively short time period, standard measures of inefficiency such as efficiency scores or proxies such as the cost-to-income ratio are less likely to capture movements in monitoring costs and managers' decisions to raise or reduce interest margins to adjust their risk exposure. Specifically, in this paper we construct a profitability-adjusted net interest margin measure as a proxy of the cost of intermediation which captures movements in the interest margin that are not linked to changes in profitability. As a result, our measure captures changes in price mark up (margin setting) behavior and in managers' risk tolerance and/or monitoring effort that are not associated with lower or higher profitability.

In Naceur and Kandil (2009), an increase in the cost of intermediation (net interest margin) due to a higher capital adequacy ratio is followed by an increase in bank profitability. In our setting, by accounting for possible governance issues, we consider that self-interested managers are more likely to exist in a bank, when an increase in the cost of intermediation is followed by a decrease in a bank's profitability. In this case, a rise in the cost of intermediation can be due to an excessive increase in monitoring costs borne by managers who dominate banks ${ }^{4}$. Therefore, following Demirgüc-Kunt and Huizinga (1999), and

\footnotetext{
${ }^{2}$ Since January 2004, entry to the banking industry has been tightened with a minimum capital requirement of 3 trillion Rupiah (US\$335 million) while all types of banks including banks established by regional governments should also reach a minimum capital of 100 billion Rupiah by 2010 and 80 billion Rupiah by the end of 2008 . These regulations are well-known as the Indonesian Banking Architecture established on January, 2004.

${ }^{3}$ Bernanke (1983) defines the cost of intermediation as the cost of channelling funds from the ultimate savers/lenders into the hand of good borrowers, which includes screening, monitoring, accounting costs, and expected losses by bad borrowers.

${ }^{4}$ Coleman et al. (2006) consider that banks with superior monitoring efforts are able to charge a higher cost of intermediation. Chen et al. (2000) also highlight the positive link between monitoring activities and loan spreads in the U.S. branches of Japanese banks.
} 
Demirgüc-Kunt et al. (2004) we consider the cost of intermediation, i.e. the bank's net interest margin, as a measure of bank inefficiency. However, to go further in our investigation we also construct profitability-adjusted interest margins.

In addition, our motivation to address the issue of managerial self-interest is driven by the implementation of the Single Presence Policy (SPP) in Indonesia as of August 2006. Under the SPP, bank shareholders are only allowed to become controlling shareholders in one single banking institution, which enhances ownership concentration. However, the SPP exempts: (1) a controlling shareholder in two banks that have different lines of businesses (for example a conventional commercial bank and an Islamic bank), (2) a controlling shareholder in two banks one of which is a joint-venture bank, (3) A Bank Holding Company (BHC) that is set up to circumvent the Central Bank regulation concerning the SPP and (4) Temporary stakes by the Indonesian Deposit Insurance Corporation in the framework of bank recovery policies.

In the meantime, Bank Indonesia as the regulator faces challenges in implementing the SPP in banks with different ownership types. The previous literature highlights that bank managers' decisions in terms of risk taking can be influenced by the ownership type of banks. State-owned banks usually tend to erode bank efficiency and to increase risk (Shleifer, 1998; Shleifer and Vishny, 1998). However, Hadad et al (2009) show that state-owned banks in Indonesia are the most efficient ones. Moreover, the presence of foreign ownership is perceived to increase the level of competition in the banking industry and hence to improve bank efficiency (Denizer, 2000; Lensink and Hermes, 2003). Because the impact of ownership type on bank performance remains unclear, we further examine the impact of bank capital on inefficiency, risk, and profitability with respect to bank ownership type. This allows to possibly infer the presence of self-interested managers in each bank ownership type.

Likewise, bank inefficiency with regard to intermediation activities has also become a major problem in Indonesian banks. The 2010 Indonesian Banking Statistics reports that the cost-to-income ratio, measured by the ratio of operating expenses to operating income, reached $89.5 \%$ in 2005 and $92.77 \%$ at the beginning of 2010. Surprisingly, there has yet been no formal analysis explaining such a trend. Through the process our paper also contributes to better understanding this issue.

The rest of this paper is organized as follows. Section 2 presents the institutional background. Section 3 describes our data, variables and descriptive statistics. Section 4 presents our hypotheses and econometric model. Section 5 discusses empirical results and section 6 provides robustness checks. Section 7 concludes the paper. 


\section{Institutional Background}

The capital adequacy ratio $(C A R)$ has been one of the main policy concerns in Indonesian banking since it was established two decades ago. Following the basic standard laid down in the Basel I accord, commercial banks were required to meet a minimum of $8 \%$ of the total capital ratio (Tier 1 and Tier 2). Such a regulation was implemented to moderate the adverse effect of banking competition in the aftermath of financial deregulation in the 1990s. However, at that time, banks tended to violate this regulation and responded to the competitive pressure by expanding credit to high-risk ventures which were politically connected. A large part of bank loans was found in the non-tradable sectors such as real estate, property and construction and ended up in default, which in turn forced banks to violate their reserve requirements to continue operating (Creed, 1999).

After the 1997 financial crisis, Bank Indonesia adopted regulatory forbearance by lowering the minimum requirement of the capital adequacy ratio from 8 to $4 \%$ to provide "breathing space" for banks and borrowers. Together with the International Monetary Fund (IMF), the Indonesian government implemented the special surveillance's task which is similar to the 1991 US Federal Deposit Insurance Corporation Improvement Act (FDICIA), a system of capital-based regulation based on prompt corrective action (PCA).

Aside from bank capitalization, risk management also became an important issue in Indonesian banking after the 1997 crisis. After replacing the Acts of 1992 and 1998 by the Act of 2001 in order to raise capital requirements to $8 \%$ again, Bank Indonesia issued a risk management framework (PBI No. 5/8/PBI/2003) for commercial banks as of May 19, 2003. This framework was applied to all types of banks in order to prepare the banking industry to move forward toward Basel II, without explicitly distinguishing small banks from large banks.

On January 2004, Indonesian Banking Architecture (IBA) introduced strict regulation of bank capital. Banking market entry was tightened with a minimum required capital of 3 trillion Rupiah (US\$335 million) while all types of banks, including banks established by regional governments were compelled to reach a minimum capital of 100 billion Rupiah by 2010. To enforce this, on June 2005, Bank Indonesia further launched the new consolidation policy. Banks were expected to hold a minimum core capital of 100 billion Rupiah (US\$11 million) by 2010 and 80 billion Rupiah by the end of 2007 .

In the aftermath of the IBA implementation, performance in Indonesian banks showed an upward trend. The banking system's total assets increased from 1,112.2 trillion Rupiah in 2002 to $1,720.9$ trillion Rupiah in 2007. Total third party funds (savings, time deposits and 
demand deposits) increased from 835.8 trillion Rupiah in 2002 to 1,305.9 trillion Rupiah in 2007, although bank credit did not significantly increase. Bank loans only amounted to 455.31 trillion Rupiah in 2007 after 410.29 trillion Rupiah in 2002. Instead, the ratio of nonperforming loans to total loans decreased from $8.1 \%$ in 2002 to $6.5 \%$ possibly due to the improvement of the capital adequacy ratio during the 2004-2007 period.

However, banks had still performed their own mergers and acquisitions operations in order to follow the IBA. As a consequence, Bank Indonesia launched the Single Presence Policy (SPP) as of August 2006, which practically forbids a company or an individual to own more than one bank. Under the SPP, controlling shareholders who do not restructure their ownership endure a prohibitive sanction preventing them from being a controlling shareholder or holding more than $10 \%$ of equity in any bank in Indonesia. Such shareholders are also to be listed in the Not Pass List during 5 years.

For some investors who dominate the banking business in Indonesia, selling stakes either fully or partially, is not considered as an ideal strategy. In fact, there are alternative solutions that can be taken by controlling shareholders as a response to the SPP, without necessarily loosing stakes. Controlling shareholders can merge all their banks or establish a Bank Holding Company (BHC) ${ }^{5}$. However, the debate regarding the SPP implementation is still open regarding the consolidation of banks with different ownership types. In dealing with such a controversy, Bank Indonesia as a regulator needs a benchmark to assess whether consolidation through the SPP is really necessary and how it could operate for banks with different ownership structures.

\section{Data, Variables and Descriptive Statistics}

\subsection{Data}

At the end of 2007, there are 104 commercial banks operating in Indonesia that consist of 5 state-owned banks, 71 private-owned banks, 18 joint-venture banks, and 11 foreignowned banks. State-owned commercial banks are commercial banks whose shares are entirely owned by the government. Private-owned commercial banks are owned by private investors. Joint-venture commercial banks are commercial banks founded jointly by two parties: the first group consists of one or more commercial banks based in Indonesia and owned by Indonesian citizens and/or an Indonesian legal entity owned by Indonesian citizens; the second group

\footnotetext{
5 According to Indonesian Banking Architecture issued by BI in 2004, the number of commercial banks in Indonesia should be around 35-58 banks in 2010. Thus, if establishing a BHC is chosen by all controlling shareholders, the BI purpose for reducing the number of banks in 2010 cannot be achieved as well, since the creation of BHCs will add a new entity of banks in the financial system.
} 
consists of one or more banks that are domiciled outside the country. The maximum capital allowed for the second group is $85 \%$ of total capital in establishing a joint-venture bank. Foreign-owned commercial banks are fully owned by foreign investors.

In this paper, we use monthly bank balance sheet and income statement data provided by the Central Bank of Indonesia, for 99 commercial banks covering the 2004-2007 period. Our sample consists of 5 state-owned banks, 65 private-owned banks, 18 joint-venture banks, and 11 foreign-owned banks, representing more than $96 \%$ of the total assets of Indonesian commercial banks. We also retrieve macroeconomic-level data from the Bureau of Statistics of Indonesia. Since we intend to analyze the interactions between capital ratios, inefficiency and risk taking, we consider that these variables are simultaneously determined.

Following Altunbas et al. (2007), we define the capital ratio (EQTA) as the ratio of equity to total assets. Since this measure is a standard measure of leverage, it allows us to directly deal with possible agency problems between shareholders and managers which can be due to an increase in equity.

Since our focus on bank inefficiency is associated with bank intermediation activities, we account for such inefficiency by two alternative proxies of the cost of intermediation (INTCOST). This is because, as argued above, we use monthly data for a relatively short time period and thus, standard measures of inefficiency such as efficiency scores or proxies such as the cost-to-income ratio or the overhead cost ratio are less likely to capture movements in monitoring costs and managers' decisions to raise or reduce interest margins to adjust their risk exposure. Demirgüc-Kunt et al. (2004) use the net interest margin (NIM) and the ratio of overhead costs to total assets as proxies of the cost of intermediation to study the impact of market structure, regulation, and institutions on the cost of intermediation. Demirgüc-Kunt and Huizinga (1999), and Dabla-Norris and Floerkemeier (2005) also use a similar approach using the ratio of net interest income to total assets as the proxy of net interest margin ${ }^{6}$. In this paper, we therefore focus on the two variables based on the net interest margin and the personnel costs ratio.

As a first step, we measure net interest margin (NIM) by computing the ratio of net interest income to total assets. However, an increase in bank net interest margin can also reflect a higher profitability and not necessarily an increase in bank intermediation cost.

\footnotetext{
${ }^{6}$ An unbiased measure of the pure intermediation margin would be the difference between the lending rate and the cost of deposits. However, such data are not available in the Indonesian banks' income statements. Our measure of the cost of intermediation implicitly assumes that the other interest revenues (e.g on securities) and interest expenses (e.g. on interbank borrowing) reflect competitive markets across banks. This assumption is also introduced by Claeys and Vennet (2008) due to data unavailability.
} 
Therefore, as a second step, we also construct a measure of profitability-adjusted bank intermediation cost. Specifically, we use the residual terms of a regression of NIM on bank profitability both measured by the return on assets $(R O A)$ and the return on equity $(R O E)^{7}$. This variable, RNIM, is expected to capture movements in the net interest margin that are not related to changes in bank profitability. As a result, our measure captures changes in margin setting behavior and in managers' risk tolerance and/or monitoring effort which are not linked with profitability motivation. For instance, an increase (decrease) in RNIM can be interpreted as a per se safer (riskier) behavior which is, by construction, uncorrelated with profitability. Identically, an increase in RNIM can be understood as more effort to monitor borrowers or more costly monitoring which are not directly motivated by a higher required profitability.

Meanwhile, for the personnel expenses variable, we use the ratio of personnel expenses to gross operating revenue (PERSON). PERSON reflects all personnel costs related to bank operations including loan monitoring activities. To sum up, the cost of intermediation measure (INTCOST) consists, alternately, of RNIM or PERSON.

Moreover, to capture bank performance (PERFORM), we use several alternative proxies associated with bank risk and profitability. To account for default risk, we use the Zscore that indicates the number of standard deviations that the bank's return on equity ( $R O E)$ has to drop below its expected value before equity is depleted. Thus, a higher Z-score is associated with a lower bank insolvency risk. The Z-score is defined as:

$$
\mathrm{ZROE}_{i, t}=\frac{1+\operatorname{MROE}_{i, t}}{\operatorname{SDROE} E_{i, t}}
$$

where SDROE is the standard deviation of ROE, while MROE is the average value of ROE. Both SDROE and MROE are computed on the basis of observations of ROE from time $t$ to $t-$ 5 (a six period-based rolling window). Alternatively, as a proxy of risk taking, we also consider SDROE as the dependent variable. Finally, in order to measure profitability, we draw the measures that are commonly used in the literature. These consist of the return on equity $(R O E)$ and the return on assets (ROA). To sum up, PERFORM is either ZROE, SDROE, ROE or ROA.

\subsection{The Determinants of the Capital Ratio}

We incorporate INTCOST as an endogenous regressor even though, as noted by Altunbas et al. (2007), the impact of bank efficiency on bank capital is ambiguous.

\footnotetext{
${ }^{7} R O E$ is the ratio of net income to total equity, while $R O A$ is the ratio of net income to total assets.
} 
Meanwhile, since the capital ratio is an indicator of the bank's safety, this ratio can be influenced by either bank risk or profitability. We thus consider bank performance measures $($ PERFORM) as an endogenous regressor.

Bank size can also matter in explaining bank capital management. To account for this dimension, we include the logarithm of bank total assets (SIZE) as an explanatory variable. Larger banks hold lower capital ratios due to their comparative advantage in terms of economies of scale in monitoring and screening activities as well as in terms of product diversification. Also, from a safety net perspective (systemic risk) larger banks can be viewed as 'Too-Big-To-Fail' (TBTF) or 'Too-Big-To-Discipline-Adequately' (TBTDA) (Kane 2000; Mishkin 2006) ${ }^{8}$. Thus, we expect a negative relationship between SIZE and the capital ratio.

Besides bank size, the capital ratio can also depend on the extent of loan activities in the balance sheet. We therefore include the ratio of loans to total asset (LOAN). LOAN is expected to have a positive effect on the bank's capital ratio, since more bank capital is needed to cover risk incurred by the loan activities (Jokipii et al., 2008; Ayuso et al., 2004).

In addition, some empirical papers shed light on the procyclicality issue of bank capital (Jokipii et al., 2008; Ayuso et al., 2004; Borio et al., 2001). Following Schaeck and Cihák (2007), we include the growth of real gross domestic product (GDPG) as one of the determinants of bank capital ratios. $G D P G$ is based on the quarterly data of real gross domestic product taken from the Bureau of Statistics of Indonesia.

Bank regulation may also play a crucial role in disciplining banks' behavior (Milne, 2002). Thus, we include a regulatory dummy variable to capture the implementation of the Indonesian Banking Architecture (IBA). This dummy variable takes the value of 1 as of June 2005 and 0 otherwise.

Finally, as the ownership type of banks can influence bank behaviour in managing their capital ratio (Memmel and Raupach, 2007), we also include four bank ownership dummy variables: state-owned banks $(S O B)$, private-owned banks $(P O B)$, joint-venture banks $(J V B)$ and foreign-owned banks $(F O B)$, as explanatory variables ${ }^{9}$.

\footnotetext{
${ }^{8}$ In Indonesia, a formal deposit insurance system was introduced in March 2007.

${ }^{9} \mathrm{SOB}$ is constructed by assigning a value of 1 when a bank is state-owned, and zero otherwise. $P O B, J V B, F O B$ are constructed analogically with a value of 1 when a bank is privately owned, joint-venture owned, and foreign owned, respectively, and zero otherwise.
} 


\subsection{The Determinants of the Cost of Intermediation}

Since we intend to analyze the relationship between the capital ratio and bank intermediation cost, we directly include the capital ratio (EQTA) as an endogenous regressor. Besides, we also incorporate bank performance (PERFORM) as an endogenous regressor, in order to build a simultaneous equations system. However, the expected sign may vary regarding the relationship between bank performance (risk and profitability) and the cost of intermediation. The sign will depend on the expertise of banks' managers to manage and monitor bank portfolios.

In the meantime, several papers show that bank concentration can influence the cost of intermediation (Demirgüc-Kunt and Huizinga, 1999; Demirgüc-Kunt et al., 2004; Naceur and Kandil, 2009, etc). A higher degree of concentration in the banking industry enables banks to increase their lending rate and hence the cost of intermediation. In this paper, bank concentration (CFIVE) is measured by the total asset share of the five largest banks in the banking system. Market power is also a crucial determinant of the cost of intermediation. There are three hypotheses explaining the link between market structure and the cost of intermediation. First, the structure-conduct-performance (SCP) hypothesis emphasizes a positive relationship between a bank's market power and the cost of intermediation due to non-competitive pricing behaviour in a concentrated market. Second, the relative-market hypothesis highlights that only banks with higher product differentiation capacity can benefit from non-competitive pricing in a concentrated market (Berger, 1995). Third, the efficientstructure hypothesis suggests a negative relationship between operational efficiency and the cost of intermediation. To account for market power and efficiency, we introduce the bank's market share $(M P O W)$, measured by the ratio of a bank's total assets to the overall assets of the banking system and the ratio of operating expenses to total assets (OVERHEAD) as control variables. The expected sign of $M P O W$ is undetermined but the expected relationship between OVERHEAD and the cost of intermediation is positive according to the efficientstructure hypothesis (Naceur and Kandil, 2009).

Moreover, we also include the ratio of loans to deposits $(L D R)$ as a liquidity measure, wherein deposits consist of demand deposits, saving and time deposits. Higher $L D R$ denotes lower bank liquidity indicating that a bank faces the risk of not having sufficient cash reserves to cope with deposit withdrawals. Predictions vary regarding the impact of liquidity on the cost of intermediation. On the one hand, a higher $L D R$ can force banks to reduce the cost of intermediation as they intend to reduce non-earning assets (increase loan activities) in order to maintain their profitability (Naceur and Kandil, 2009). The reduction in the cost of 
intermediation can be also due to competition in the deposit market (Demirgüc-Kunt et al., 2004). On the other hand, a higher $L D R$ can encourage banks to increase the cost of intermediation in order to maintain profit when credit demand is limited due to tight conditions on the financial market. We also include the four ownership type dummy variables ( $S O B, P O B, J V B, F O B$ ), as bank ownership type may influence the capital ratio, the cost of intermediation, and risk. However, prediction varies with regard to these relationships, since they are empirical in nature.

\subsection{The Determinants of Bank Performance}

We directly include the ratio of equity to total assets (EQTA) and the cost of intermediation measures (INTCOST) as endogenous regressors. We also include the ratio of total loans to total assets $(L O A N)$. Loans (LOAN) are at the core of bank risk and profitability captured by PERFORM, but the expected link between LOAN and PERFORM depends on the dimension, either risk or profitability, which is represented by PERFORM. The relationship between $L O A N$ and risk measures as well as between $L O A N$ and profitability measures could be negative. Following Bris and Cantale (2004), such a negative relationship can be due to the presence of self-interest managers, where risky but more profitable loans are bypassed by managers who dominate shareholders in bank portfolio allocation decisions. Moreover, we include the ratio of total deposits to total asset (DTA), wherein deposits consist of savings, demand deposits and time deposits. Since deposits are insured, a higher DTA potentially increases bank moral hazard to fund risky projects. Meanwhile, a higher DTA also reflects an increase in leverage risk. Thus, we expect a positive relationship between DTA and bank risk, but the link between DTA and bank profitability remains ambiguous. The ratio of loan loss provisions to total loans $(L L P)$ is also considered as an explanatory variable in the PERFORM equation. Since $L L P$ is a credit risk measure, we expect a positive relationship between $L L P$ and bank risk, but how $L L P$ affects bank profitability is undertermined. Finally, we also incorporate $G D P G$ to account for macroeconomic performance, and the four ownership type dummies ( $S O B, P O B, J V B, P O B)$, since ownership type may influence bank risk and returns.

\subsection{Data Selection}

We impose several restrictions on our data to ensure that our work is conducted on a clean sample. First, we exclude all negative values of equity since there is no information on whether or not such negative values are related to the government's bailout policy. We have cross-checked these data with data from a different source, Bankscope, and have noticed that 
equity values provided by Bankscope for such banks are positive. Second, we eliminate the extreme bank/year observations (2.5\% highest values) for the ratio of loans to deposits $(L D R)$, since $L D R$ has a right-skewed distribution. For the return on equity ratio $(R O E)$ and the ratio of personnel expenses to gross operating revenue (PERSON), we exclude their $2.5 \%$ lowest and $2.5 \%$ highest values, since their distribution exhibits very long tails on both sides. Finally, we also exclude all values above $100 \%$ for the ratio of deposits to total assets (DTA).

\subsection{Descriptive Statistics}

The descriptive statistics are reported in Table 1 while correlations are detailed in Table 2. The variables do not exhibit major colinearity issues, except for MPOW and SIZE or $D T A$ and $R O E$ which we do not concurrently use as regressors in our estimations.

Insert Table 1 and 2 here

\section{Hypotheses and Econometric Specification}

\subsection{Hypotheses}

The objective of this paper is twofold. First, we examine if there might be a selfinterested manager effect in Indonesian banks by scrutinizing the link between capital, the cost of intermediation, risk, and profitability; second, we seek to identify banks' ownership types which are more likely to suffer from a possible managerial self-interest problem.

Regarding the first objective, we test the following hypothesis based on the theoretical contribution of Bris and Cantale (2004):

Hypothesis 1: Managers in Indonesian banks are likely to be self-interested; if so, a higher capital adequacy ratio would be associated with an increase in the cost of intermediation due to monitoring costs borne by bank managers who behave conservatively by increasing the safety of loan portfolios but by making them less profitable.

Hypothesis 1 is not rejected if a higher capital ratio is associated with an increase in the cost of intermediation but a decrease in risk and profitability. In such a case, we conclude that 
there is a strong presumption that managers are likely to be self-interested ${ }^{10}$. To examine Hypothesis 1, we construct the following simultaneous equations model.

$$
\begin{aligned}
& \mathrm{EQTA}_{i, t}=\alpha_{0 i}+\alpha_{1} \operatorname{INTCOST}_{i, t}+\alpha_{2} \text { PERFORM }_{i, t}+\alpha_{3} \operatorname{SIZE}_{i, t}+\alpha_{4} \operatorname{LOAN}_{i, t} \\
& +\alpha_{5} G D P G_{t}+\alpha_{6} I B A_{t}+\alpha_{7} S O B_{i}+\alpha_{8} P O B_{i}+\alpha_{9} J V B_{i}+\alpha_{10} F O B_{i}+\gamma_{i, t} \\
& \operatorname{INTCOST}_{i, t}=\beta_{0 i}+\beta_{1} \text { EQTA }_{i, t}+\beta_{2} \text { PERFORM }_{i, t}+\beta_{3} \text { CFIVE }_{t}+\beta_{4} \text { MPOW }_{i, t} \\
& +\beta_{5} \text { OVERHEAD }_{i, t}+\beta_{6} \text { LDR }_{i, t}+\beta_{7} S O B_{i} \\
& +\beta_{8} P O B_{i}+\beta_{9} J V B_{i}+\beta_{10} F O B_{i}+\varepsilon_{i, t} \\
& \text { PERFORM }_{i, t}=\delta_{0 i}+\delta_{1} \text { EQTA }_{i, t}+\delta_{2} \text { INTCOST }_{i, t}+\delta_{3} \operatorname{LOAN}_{i, t}+\delta_{4} \text { DTA }_{i, t} \\
& +\delta_{5} L L P_{i, t}+\delta_{6} G D P G+\delta_{7} S O B_{i}+\delta_{8} P O B_{i}+\delta_{9} J V B_{i}+\delta_{10} F O B_{i}+\omega_{i, t}
\end{aligned}
$$

The set of exogenous regressors consists of SIZE, LOAN, GDPG, IBA, SOB, POB, JVB, FOB, CFIVE, MPOW, OVERHEAD, LDR, DTA, and LLP.

The simultaneous equations model in System (1) is comparable to prior models on bank capital, efficiency and risk (Altunbas et al., 2007; Kwan and Eisenbeis, 1997). Under Hypothesis $1, \beta_{1}$ and $\delta_{1}$ are expected to be positive and negative respectively. There are three structural equations in (1), where $\gamma_{i, t}, \varepsilon_{i, t}$ and $\omega_{i, t}$ are residual terms, and $\alpha_{0 i}, \beta_{0 i}$ and $\delta_{0 i}$ are individual fixed effects. The variables EQTA, INTCOST and PERFORM are endogenously determined. The first equation (EQTA) contains the factors that are expected to influence banks' capital ratios. In the second equation (INTCOST), we attempt to examine whether a higher capital ratio $(E Q T A)$ is associated with an increase in the cost of intermediation. In the third equation (PERFORM), we examine whether a higher capital ratio is associated with a decrease in risk and profitability. If bank managers are more likely to be self-interested, we should find $\beta_{1}>0$ and $\delta_{1}<0$ :a higher capital ratio is associated with an increase in the cost of intermediation, but a decrease in risk and profitability.

It is also well admitted that bank managerial decision and bank risk taking can be influenced by the ownership type and ownership structure of banks (Iannotta et al., 2007 and Barry et al., 2011). Ownership types that received a particular attention in Indonesian commercial banks are state-owned banks $(S O B)$, private-owned banks $(P O B)$, joint-venture

\footnotetext{
${ }^{10}$ To cope with self-interested managers, Bris and Cantale (2004) set a condition in which bank shareholders need to offer managers an optimal compensation package to restore efficiency. This compensation package is a function of managers' efforts. However, this issue is beyond the scope of our paper.
} 
banks $(J V B)$, and foreign-owned banks $(F O B)$. Our second objective is therefore to investigate whether such relationships depend on the ownership type of banks. For this purpose, we specify Hypothesis 2 as follows:

Hypothesis 2 : The impact of a higher capital adequacy ratio on the cost of intermediation, risk and profitability is not similar for banks with different ownership types.

Therefore, we attempt to reject the null :

$$
\mathrm{H}_{0}:\left\{\begin{array}{l}
\beta_{1 \mathrm{~S}}=\beta_{1 \mathrm{P}}=\beta_{1 \mathrm{JV}}=\beta_{1 \mathrm{~F}} \\
\text { and } \\
\delta_{1 \mathrm{~S}}=\delta_{1 \mathrm{P}}=\delta_{1 \mathrm{JV}}=\delta_{1 \mathrm{~F}}
\end{array}\right.
$$

in the following model (2) in which interaction variables are added to capture such differential effects:

$$
\begin{aligned}
& E_{\text {ETA }}{ }_{i, t}=\alpha_{0 i}+\alpha_{1} \text { INTCOST }_{i, t}+\alpha_{2} \text { PERFORM }_{i, t}+\alpha_{3} \text { SIZE }_{i, t}+\alpha_{4} \operatorname{LOAN}_{i, t} \\
& +\alpha_{5} G D P G_{t}+\alpha_{6} I B A_{t}+\alpha_{7} S O B_{i}+\alpha_{8} P O B_{i}+\alpha_{9} J V B_{i}+\alpha_{10} F O B_{i}+\gamma_{i, t} \\
& \operatorname{INTCOST}_{i, t}=\beta_{0 i}+\beta_{1 S} \operatorname{SOB}_{i} * E Q T A_{i, t}+\beta_{1 P} P O B_{i} * E Q T A_{i, t}+\beta_{1 J V} J V B_{i} * E Q T A_{i, t} \\
& +\beta_{1 F} \text { FOB }_{i} * E_{\text {ETA }}+\beta_{5} \text { PERFORM }_{i, t}+\beta_{6} \text { CFIVE }_{t}+\beta_{7} \text { MPOW }_{i, t} \\
& +\beta_{8} \text { OVERHEAD } D_{i, t}+\beta_{9} L D R_{i, t}+\varepsilon_{i, t} \\
& \text { PERFORM }_{i, t}=\delta_{0 i}+\delta_{1 S} \text { SOB }_{i} * E_{\text {ETA }}+\delta_{1 P} \text { POB }_{i} * E_{\text {ETA }}+\delta_{1, t} J V B_{i} * E Q T A_{i, t} \\
& +\delta_{1 F} F_{i} * E Q T A_{i, t}+\delta_{5} I N T C O S T_{i, t}+\delta_{6} L_{i, t}+\delta_{7} D^{2 T A_{i, t}} \\
& +\delta_{8} L L P_{i, t}+\delta_{9} G D P G_{t}+\omega_{i, t}
\end{aligned}
$$

\subsection{Econometric Method}

In estimating System (1), we attempt to overcome various econometric problems that may arise.

First, we handle endogeneity issues regarding all our variables using the Generalized Method of Moments (GMM) for two reasons: this method is robust to the errors distribution and is considered as more efficient than Two-Stages Least Squares (2SLS) because it accounts for heteroskedasticity (Hall, 2005).

Second, the right-hand side of each equation in System (1) comprises four time-invariant variables related to bank ownership type $(S O B, P O B, J V B$, and $F O B)$. In this regard, individual fixed effects could not be taken directly into account in the GMM estimation. Meanwhile, correction for individual fixed effects is essential to tackle the problem of 
possible omitted variables. To deal with this problem, we follow Plumper and Troeger $(2007)^{11}$.

Third, and most probably, the three errors are cross - correlated in System (1). Therefore, we opt for a simultaneous equations approach in solving System (1) with a covariance matrix which accounts for cross equation errors correlation.

\section{Empirical Results}

Tables 3 and 4 sum up the results of the GMM estimation of System (1) when we use respectively the profitability-adjusted net interest margin $(R N I M)$ and the ratio of personnel expenses to operating income ratio (PERSON) as proxies for the cost of intermediation. In regressions 1 to 4 we alternately consider the four definitions of PERFORM that consist of risk and profitability proxies (ZROE, SDROE, ROE and ROA).

\section{Insert Table 3 and Table 4 here}

To assess Hypothesis 1, we proceed in two steps. First, we examine the relationship between EQTA and bank intermediation cost measured by both the profitability-adjusted net interest margin $(R N I M)$ and the personnel expenses ratio (PERSON). Second, we examine the relationship between EQTA and bank risk (ZROE or SDROE) and profitability (ROE or ROA).

In the first step, Table 3 shows that a higher capital ratio is associated with an increase in the cost of intermediation. Such a relationship is shown by the positive significant coefficients associating EQTA and RNIM in Regression 1 to 3 at the $1 \%$ significance level. We also find a positive significant relationship between EQTA and the personnel expenses ratio (PERSON) at the 1\% significance level, as shown in Regression 1, 2 and 4 in Table 4.

In the second step, we examine the link between the capital ratio and performance. Table 3 shows that a higher capital ratio is associated with a decrease in insolvency risk $(Z R O E)$, risk taking (SDROE), and profitability ( $R O E$ and $R O A)$ as shown in Regressions 1 to 4. In Table 4, we also find similar relationships, although EQTA is not significant in the ROA equation.

On the basis of these two procedures, Hypothesis 1 cannot be rejected and hence, according to our results, there is a strong presumption that bank managers are likely to be

\footnotetext{
${ }^{11}$ As a first step all the variables are centred on their individual means, such that all time invariant regressors disappear. Then, we estimate individual fixed effects which are, in turn, regressed on time invariant regressors. We obtain the unexplained components of fixed effects which are, eventually, jointly reintroduced in the model with the full set of regressors (both time varying and non-time varying).
} 
self-interested. In other words, bank managers might be driving banks to become safer but unfortunately less profitable, since more risky but also more profitable loans are bypassed.

To investigate whether the behaviour of managers is similar in banks with different ownership types, we consider the results obtained by estimating System (2). The interaction terms associating EQTA and the four ownership dummies are the key variables for this purpose. Tables 5 and 6 summarize results with RNIM and PERSON as proxies of the intermediation cost respectively.

\section{Insert Table 5 and Table 6 here}

In state-owned banks, a higher capital ratio is associated with an increase in the cost of intermediation measured by the profitability-adjusted net interest margin $(R N I M)$ and the personnel expense ratio (PERSON) as shown in Tables 5 and 6, respectively. However, there is no significant impact of the capital ratio on risk and profitability of state-owned banks. Such findings may highlight that state-owned banks exhibit greater intermediation cost when the capital ratio increases. However, there is no presumption regarding the possible presence of self-interested managers in state-owned banks.

In private-owned banks, a higher capital ratio is associated with an increase in the cost of intermediation, as measured by either RNIM (Table 5 - Regressions 1) or PERSON (Table 6 - Regressions 2 and 3). A higher capital ratio is also associated with a decrease in risk, measured by either ZROE (Table 5 - Regressions 1; and Table 6 - Regression 1) or SDROE (Table 5 - Regression 2). Moreover, there is also a negative relationship between the capital ratio and bank profitability as shown in both Table 5 (Regressions 3 and 4) and Table 6 (Regression 3). Therefore, for private-owned banks Hypothesis 1 is not rejected and hence, we can suspect the presence of self-interested managers in such institutions.

For joint-venture banks, the capital ratio is significantly and positively linked to the profitability-adjusted net interest margin, as shown in Table 5 (Regressions 1, 3 and 4), but negatively related to the personnel expense ratio as shown in Table 6 (Regressions 1, 3, and 4). From Table 5 (Regressions 1 and 2), an increase in the capital ratio positively affects insolvency risk and risk taking. Meanwhile, there is a weak negative relationship between the capital ratio and bank profitability (Table 5 - Regression 3; and Table 6 - Regression 3). These relationships indicate that the managerial self-interest problems are less likely to exist in joint-venture banks. 
Finally, for foreign-owned banks, Table 6 (Regressions 1 and 3) shows that a higher capital ratio is associated with an increase in the personnel expense ratio. Meanwhile, there is a positive relationship between the capital ratio and insolvency risk (Table 5 - Regression 1 ). Similarly to joint-venture banks, the positive link between bank capital and risk also holds for foreign-owned banks as shown in Table 6 (Regression 2). In addition, a higher capital ratio is also associated with an increase in profitability (Table 5 - Regression 4, and Table 6 Regression 3). Similarly to joint-venture banks, the managerial self-interest problems are less likely to exist in foreign-owned banks.

On the whole, our findings show that there is at least one ownership type (privateowned banks) in which the presence of self-interest managers can be suspected. Hypothesis 2 therefore holds as the null $\left(\mathrm{H}_{0}\right)$ is rejected. Such commercial banks are dominant in Indonesia (71 banks out of a total of 104 commercial banks) and in our sample (65 banks out of a total of 99 banks).

\section{Robustness Checks}

Beyond the use of various measures of inefficiency, risk and profitability to ensure the robustness of our results, we also consider alternative estimation methods and other specifications for the simultaneous equations model ${ }^{12}$. First, instead of using the GMM method to estimate (2) and (5), we use the two stages least squares (2SLS) method and the three stage least squares (3SLS) method. Our main results remain identical. Second, we introduce four ownership dummies $(S O B, P O B, J V B$, and $F O B)$ into each structural equation in System (2). Hence, System (2) has to be estimated by using the method of Plumper and Troeger (2007). Here again, our main results remain unchanged.

Moreover, we change our proxy of bank risk following Boyd et al. (2006) which allow the $Z$-score to be volatile in each period. However, we use $R O E$ instead of drawing the ratio of net income to total assets (ROA) used by Boyd et al. (2006). Formally let $i$ be a bank index and $t$ be a period index, then the alternative $Z$-score is defined as

$$
\mathrm{ZROE}_{i, t}^{*}=\frac{1+\operatorname{ROE}_{i, t}}{A D R O E_{i, t}},
$$

where $A D R O E_{i, t}=\left|R O E_{i, t}-\frac{1}{T} \sum_{t} R O E_{i, t}\right|$ is bank i time specific absolute deviation of the return on equity $(R O E)$. The average of $R O E$ is computed for the full sample period and a different value of $A D R O E$ is assigned for each period. Besides $Z R O E^{*}$, we examine another

\footnotetext{
${ }^{12}$ The results of robustness checks are not displayed in the paper but are available from the authors on request.
} 
risk measure defined as the logarithm of the absolute deviation of the return on equity ( $L N A D R O E$ ) in a bank for each period. A higher value of $L N A D R O E$ is associated with an increase in asset risk due to risk-taking strategies that increase income volatility. Using these alternative risk measures and performing the GMM, 2SLS, and 3SLS estimations for System (1) and (2), our main results discussed in Section 5 remain consistent.

Finally, we consider NIM (the ratio of net interest income to total assets) as another proxy of the cost of intermediation. This procedure is consistent with Demirgüc-Kunt et al (2004). By conducting the GMM, 2SLS, and 3SLS for System (1) and (2), our main findings are not altered.

\section{Conclusion}

This paper provides empirical evidence on the link between bank capital and risk under the managerial self-interest hypothesis which, to our knowledge, has not been empirically explored in the literature. In order to capture the presence of self-interested managers, we consider that a higher cost of intermediation or higher inefficiency due to an excessive reliance on monitoring following an increase in capital leading to lower profitability could be associated with a higher degree of managerial self-interest.

Our GMM estimations applied on monthly Indonesian data for the 2004-2007 period show that managers in Indonesian banks are likely to be self-interested. A deeper investigation shows that among the different bank ownership categories, private-owned banks are the ones which actually suffer from the presence of self-interested managers. Therefore, in the case of Indonesia any policy aiming to enforce shareholder domination, for instance through the Single Presence Policy, should take private-owned banks into very close consideration. Such a policy should mitigate inefficiency problems in private-owned banks due to the presence of self-interested managers but also aim to enhance the bank ownership consolidation process, since most of Indonesian banks are private-owned banks.

Moreover, foreign-owned banks exhibit greater performance compared to other types banks, since a higher capital ratio in foreign banks is associated with an increase in profitability without necessarily implying an increase in insolvency risk and risk taking. This finding further suggests that increasing foreign participations in the process of banking sector consolidation in Indonesia can be necessary.

\section{References}


Aggarwal, R., Jacques, K.T., 2001, The impact of FDICIA and prompt corrective action on bank capital and risk. Journal of Banking and Finance 25, 1139-1160.

Altunbas, Y., Carbo, S., Gardener, E.P.M., Molyneux, P., 2007. Examining the relationships between capital, risk and efficiency in European banking. European Financial Management 13 (1), 49-70.

Barry, T.A., Lepetit L., and Tarazi A., 2011. Ownership structure and risk in publicly held and privately owned Banks. Journal of Banking and Finance 35(5), 1327-1340

Bernanke, B., 1983. Non-monetary effects of the financial crisis in the propagation of the Great Depression. American Economic Review 73 (3), 257-276.

Berger, A.N., 1995. The profit-structure relationship in banking-Tests of market-power and efficient-structure hypotheses. Journal of Money, Credit and Banking 27, 404-431.

Besanko D., Kanatas, G., 1996. The regulation of bank capital : Do capital standards promote bank safety?. Journal of financial intermediation 5, 160-183.

Bischel, R., Blum, J.M., 2004. The relationship between risk and capital in Swiss commercial banks: a panel study, Applied Financial Economics 14, 591-597.

Blum, J.M., 1999. Do capital requirements reduce risk in banking?. Journal of Banking and Finance 23, 755-771.

Blum, J.M., 2003. The impact of bank capital requirements on bank's incentive to monitor and to hold excess capital. Swish National Banks, Working Paper.

Borio, C., Furfine, C., Lowe, P., 2001. Procyclicality of the financial system and the financial stability: Issues and policy options. Bank for International Settlements, Switzerland, Working Paper No.1, pp. 1-57.

Boyd, J.H., De Nicolo, G., Jalal, A.M., 2006. Bank risk-taking and competition revisited: New theory and new evidence. IMF, Working Paper No. 06/297.

Bris, A., Cantale, S., 2004. Bank capital requirement and managerial self-interest. Quarterly Review of Economics and Finance 44, 77-101.

Chen,C.R., Steiner,T.L., Whyte, A.M., 1998. Risk-taking behavior and management ownership in depository institutions. Journal of Financial Research 21,1-16.

Claeys, S., \& R.V. Vennet. (2008), Determinants of Bank Interest Margin in Central and Eastern Europe: A Comparison with the West, Economic System, 32, 197-216.

Cornwell, C., P.Schmidt, \& D. Wyhowski. (1992), Simultaneous Equation and Panel Data, Journal of Econometrics, 51, 151-181.

Creed, A. 1999. Everything not in moderation: Indonesia's excess the undermining of the Indonesian banking system. The Monitor: Journal of International Studies 6(1). 
Dabla-Norris, E., Floerkemeier, H., 2007. Bank efficiency and market structure : what determines bank spreads in Armenia ?. IMF Working Paper No. 134.

Demirgüc-Kunt, A. Huizinga, H., 1999. Determinants of commercial bank interest margins and profitability: Some international evidence. World Bank, Working Paper WPS 1900.

Demirgüc-Kunt, A., Laeven, L., Levine, R., 2004. Regulations, market structure, institutions and the cost of financial intermediation. Journal of Money, Credit and Banking 36 (3), 593622.

Denizer, C., 2000. Foreign bank entry in Turkey's banking sector, 1980-1997, in: S.Claessens and M. Jansen (eds.), The Internalization of Financial Services: Issues and Lessons for Developing Countries, Dordrecht and Boston, Kluwer Academic Press

Gorton, G., Rosen, R., 1995. Corporate control, portfolio choice, and the decline of banking. Journal of Finance 50, 1377-1420.

Hadad, M.D., Hall, M.J.B, Santoso, W., Kenjegalieva, K., Simper, R., 2009. A new approach to dealing with negative numbers in efficiency analysis: An application to the Indonesian Banking sector. Discussion Paper Series (20), Department of Economics, Loughborough University

Hall, A.R., 2005. Generalized method of moments. Oxford University Press, Oxford.

Hughes, J. P., Mester, L. J., 1994. Evidence on the objectives of bank managers. Rodney L. White Center for Financial Research, Working Paper 4-94, 37.

Iannota, G., Giacomo, N., Sironi, A., 2007. Ownership Structure, Risk and Performance in the European Banking Industry. Journal of Banking and Finance 31, 2127-2149.

Jeitschko, T., Jeung, S.D., 2005. Incentives for risk-taking in banking: A unified approach. Journal of Banking and Finance 29, 759-777.

John, K., Saunders, A., Senbet, L.W., 2000. A theory of bank regulation and management compensation. Review of Financial Studies 13, 95-125.

Kahane, Y., 1977. Capital adequacy and the regulation of financial intermediaries. Journal of Banking and Finance 1, 207-218.

Kane, E.J., 2000. Incentives for banking megamergers: What motives might regulators infer from event-study evidence? Journal of Money, Credit and Banking 32, 671-701.

Kim, D., Santomero, A.M., 1988. Risk in banking and capital requirement. Journal of Finance 43, 1219-1233.

Koehn, M. Santomero, A.M, 1980. Regulation of bank capital and portfolio risk. Journal of Finance 35, 1235-1244.

Kwan, S., Eisenbeis, R., 1997. Bank risk, capitalization and operating efficiency. Journal of Financial Services Research, 12 (2, 3), 117-31. 
Laeven, L., Levine, R. (2009). Bank governance, regulation and risk-taking. Journal of Financial Economics 93 (2), 259-275.

Lensink, R., Hermes, N., 2003. The short-term effects of foreign bank entry on domestic bank behaviour: Does economic development matter?. Journal of Banking and Finance, 27.

Lin, S. L., Penm, J. H., Garg, S. C., Chang, C. S., 2005. Risk based capital adequacy in assessing on insolvency-risk and financial profitabilitys in Taiwan's banking industry. Research in International Business and Finance 19, 111-153.

Memmel, Christoph; Raupach, Peter; 2010. How Do Banks Adjust Their Capital Ratios? Journal of Financial Intermediation, October, v. 19, iss. 4, pp. 509-28

Milne, A., 2002. Bank capital requirement as an incentive mechanism: Implications for portfolio choice. Journal of Banking and Finance 26, 1-23.

Mishkin, F.S., 2006. How big a problem is too big to fail?. Journal of Economic Literature 44, 988-1004.

Murinde, V., Yaseen, H., 2006. The impact of basel accord regulations on bank capital and risk behaviour: Evidence from the MENA region. University of Birmingham, Working Paper.

Naceur, S.B, Kandil, M., 2009. The impact of capital requirements on bank's cost of intermediation and profitability: The case of Egypt. Journal of Economics and Business 61, 70-89.

Nier, E., Baumann, U., 2006. Market discipline, disclosure and moral hazard in banking. Journal of Financial Intermediation 15, 332-361.

Palia, D., Porter, R., 2004. The impact of capital requirements and managerial compensation on bank charter value. Review of Quantitative Finance and Accounting 23, 191-206.

Pangestu, M., 2003. The Indonesian banking crisis and restructuring: Lessons and implications for other developing countries. United Nations Conference on Trade and Development, Working Paper.

Plumper, T., Troeger, V., 2007. Efficient estimation of the time-invariant and rarely changing variables in finite sample panel analysis with unit fixed effects. Political Analysis 15(2), 124130.

Repullo, R., 2004. Capital requirements, market power and risk-taking in banking. Journal of Financial Intermediation 13, 156-182.

Rime B., 2001 Capital requirements and bank behaviour: Empirical evidence for Switzerland. Journal of Banking and Finance 25, 789-805.

Saunders, A., Strock, E., Travlos, N., 1990. Ownership structure, deregulation, and bank risktaking. Journal of Finance 45, 643-654. 
Schaeck, K., Cihák, M., 2007. Banking competition and capital ratios. IMF Working Paper No. $07 / 216$

Shleifer A., 1988. State versus private ownership, Journal of Economic Perspectives, 12, $133-150$

Shleifer A., Vishny R.W., 1998. The grabbing hand: government pathologies and their cures, Harvard University Press, MA.

Sullivan, R., Spong, K.R., 2007. Managerial wealth, ownership structure, and risk in commercial banks. Journal of Financial Intermediation 16, 229-248. 


\section{APPENDIX}

Table 1. Descriptive statistics for the overall period of study

\begin{tabular}{|c|c|c|c|c|c|c|}
\hline Variables & Definition & Mean & Median & Maximum & Minimum & $\begin{array}{l}\text { Standard } \\
\text { Deviation }\end{array}$ \\
\hline SIZE & The logarithm of bank's total asset (total asset is expressed in billion Rupiah) & 14.543 & 14.413 & 19.531 & 9.466 & 1.982 \\
\hline EQTA & The ratio of equity to total asset & 0.1572 & 0.1218 & 0.9961 & 0.000068 & 0.1266 \\
\hline$R O E$ & The ratio of net income to equity & 0.0126 & 0.0098 & 0.1895 & -0.0653 & 0.0233 \\
\hline ZROE & The Z-score based on $R O E$ & 243.65 & 144.52 & 5078.34 & 6.69 & 303.55 \\
\hline SDROE & The standard deviation of $R O E$ based on the six months rolling windows. & 0.0129 & 0.0069 & 0.1583 & 0.0002 & 0.0157 \\
\hline$R O A$ & The ratio of net income to total asset & 0.0019 & 0.0017 & 0.2068 & -0.1327 & 0.0071 \\
\hline NIM & The ratio of net interest income to total asset & 0.0043 & 0.0042 & 0.1489 & -0.1007 & 0.0054 \\
\hline PERSON & The ratio of personnel expense to operating revenue & 0.3668 & 0.3423 & 1.298 & 0.00064 & 0.1852 \\
\hline$L D R$ & The ratio of total loan to total deposit & 1.5191 & 1.2536 & 9.0103 & 0.00099 & 1.0764 \\
\hline CFIVE & The total asset share of the five biggest banks in the banking industry & 0.5668 & 0.5575 & 0.6081 & 0.5419 & 0.0191 \\
\hline$M P O W$ & The bank's asset share in the banking industry & 0.0103 & 0.0014 & 0.2258 & 0.000011 & 0.0272 \\
\hline OVERHEAD & The ratio of operating expense to total asset & 0.0084 & 0.0079 & 0.1248 & 0.00054 & 0.0049 \\
\hline$G D P G$ & The quarterly growth of the real gross domestic product & 0.0463 & 0.0534 & 0.0708 & 0.0035 & 0.0223 \\
\hline$L O A N$ & The ratio of total loan to total asset & 0.5499 & 0.5795 & 0.9831 & 0.00033 & 0.1943 \\
\hline DTA & The ratio of total deposits to total asset & 0.6742 & 0.7436 & 0.9191 & 0.6327 & 0.1943 \\
\hline$L L P$ & The ratio of loan loss provision to total loan & 0.0462 & 0.0251 & 0.8073 & 0.00074 & 0.2042 \\
\hline$I B A$ & The Indonesian Banking Architecture dummy takes 1 after June 2005. & 0.6458 & 1 & 1 & 0 & 0.4783 \\
\hline$S O B$ & The state-owned bank dummy & 0.0505 & 0 & 1 & 0 & 0.219 \\
\hline$P O B$ & The private-owned bank dummy & 0.6566 & 1 & 1 & 0 & 0.4749 \\
\hline$J V B$ & The joint-venture bank dummy & 0.1818 & 0 & 1 & 0 & 0.3857 \\
\hline$F O B$ & The foreign-owned bank dummy & 0.1111 & 0 & 1 & 0 & 0.3143 \\
\hline
\end{tabular}


Table 2. Pairwise Correlations

\begin{tabular}{|c|c|c|c|c|c|c|c|c|c|c|c|c|c|c|c|c|c|}
\hline & SIZE & EQTA & $R O E$ & ZROE & SDROE & $R O A$ & NIM & PERSON & $L D R$ & CFIVE & & & & & & & \\
\hline SIZE & 1 & & & & & & & & & & & & & & & & \\
\hline EQTA & -0.4120 & 1.0000 & & & & & & & & & & & & & & & \\
\hline$R O E$ & 0.2403 & -0.1815 & 1.0000 & & & & & & & & & & & & & & \\
\hline ZROE & -0.0122 & 0.0746 & -0.0174 & 1.0000 & & & & & & & & & & & & & \\
\hline$S D R O E$ & 0.0504 & -0.1385 & 0.3248 & -0.2861 & 1.0000 & & & & & & & & & & & & \\
\hline$R O A$ & 0.0800 & 0.0325 & 0.5644 & 0.0155 & 0.1731 & 1.0000 & & & & & & & & & & & \\
\hline NIM & -0.1875 & 0.1392 & 0.1076 & -0.0017 & 0.0184 & 0.1139 & 1.0000 & & & & & & & & & & \\
\hline PERSON & -0.2555 & 0.0376 & -0.2712 & -0.0265 & 0.0945 & -0.2854 & 0.0686 & 1.0000 & & & & & & & & & \\
\hline$L D R$ & -0.0141 & -0.1695 & 0.0143 & -0.0049 & 0.0482 & -0.0492 & -0.0895 & 0.1224 & 1.0000 & & & & & & & & \\
\hline CFIVE & -0.0864 & 0.0124 & 0.0970 & 0.0035 & 0.0525 & 0.0244 & 0.0521 & 0.1010 & 0.0607 & 1.0000 & & & & & & & \\
\hline MPOW & 0.6388 & -0.1595 & 0.0877 & -0.0089 & -0.0090 & 0.0211 & -0.1212 & -0.0591 & 0.0982 & -0.0014 & 1.0000 & & & & & & \\
\hline OVERHEAD & -0.1941 & -0.0221 & -0.0782 & -0.0394 & 0.1243 & -0.1310 & 0.1321 & 0.2287 & -0.0351 & -0.0895 & -0.0846 & 1.0000 & & & & & \\
\hline$G D P G$ & -0.0289 & 0.0014 & 0.0104 & -0.0069 & -0.0244 & -0.0056 & 0.0101 & -0.0031 & 0.0048 & 0.0406 & -0.0048 & -0.0459 & 1.0000 & & & & \\
\hline LOAN & -0.0716 & -0.0893 & -0.0386 & -0.0218 & -0.0981 & -0.0152 & 0.1701 & -0.1068 & -0.5484 & -0.0457 & -0.1711 & 0.1662 & 0.0107 & 1.0000 & & & \\
\hline DTA & 0.1465 & -0.5074 & 0.0402 & -0.0564 & 0.0092 & -0.0965 & -0.0107 & 0.0805 & 0.3382 & 0.0373 & 0.1304 & 0.1631 & 0.0154 & 0.0895 & 1.0000 & & \\
\hline LLP & -0.0015 & 0.1773 & 0.0158 & 0.0100 & 0.0454 & 0.0399 & -0.0544 & 0.1117 & 0.0525 & 0.1952 & 0.0887 & -0.0842 & 0.0377 & -0.2187 & -0.2199 & 1.0000 & \\
\hline$I B A$ & 0.0862 & -0.0142 & -0.0995 & -0.0068 & -0.0286 & -0.0215 & -0.0571 & -0.1109 & -0.0618 & -0.8628 & 0.0040 & 0.1184 & -0.0719 & 0.0475 & -0.0331 & -0.1894 & 1.0000 \\
\hline
\end{tabular}


Table 3. Regression outputs with RNIM as the measure of the cost of intermediation

The models are estimated using Generalized Method of Moments (GMM) in a simultaneous equations system with individual fixed effects. $(* * *),(* *)$ and $(*)$ indicate significance at the $1 \%$, $5 \%$ and $10 \%$ levels, respectively. The $t$-statistics are reported in parentheses. Endogenous variables are the capital ratio (EQTA), the profitability-adjusted net interest margin measure (RNIM), insolvency risk (ZROE), risk-taking (SDROE) and profitability ( $R O E$ and $R O A)$. The bold fonts are introduced to assess Hypothesis 1: a higher capital ratio is associated with an increase in the cost of intermediation, but a decrease in risk and profitability.. Regression 1 uses ZROE as the dependent variable in the PERFORM equation as shown in (1), while Regressions 2 , 3, and 4 respectively use $S D R O E, R O E$, and $R O A$

\begin{tabular}{|c|c|c|c|c|c|c|c|c|c|c|c|c|}
\hline \multirow[b]{2}{*}{ Variables } & \multicolumn{3}{|c|}{ Regression 1} & \multicolumn{3}{|c|}{ Regression 2} & \multicolumn{3}{|c|}{ Regression 3} & \multicolumn{3}{|c|}{ Regression 4} \\
\hline & $E Q T A$ & RNIM & ZROE & $E Q T A$ & RNIM & SDROE & $E Q T A$ & RNIM & $R O E$ & $E Q T A$ & RNIM & $R O A$ \\
\hline $\begin{array}{l}\text { RNIM } \\
\text { SIZE }\end{array}$ & $\begin{array}{l}75.773 * * * \\
(9.129) \\
-0.021 * * * \\
(-3.835)\end{array}$ & & $\begin{array}{l}-32131 * * * \\
(-3.937)\end{array}$ & $\begin{array}{l}44.901 * * * \\
(7.362) \\
-0.092 * * * \\
(-15.512)\end{array}$ & & $\begin{array}{l}1.619 * * * \\
(6.113)\end{array}$ & $\begin{array}{l}40.957 * * * \\
(4.556) \\
-0.029 * * * \\
(-6.318)\end{array}$ & & $\begin{array}{l}4.441 * * * \\
(5.475)\end{array}$ & $\begin{array}{l}31.211 * * \\
(2.461) \\
-0.038 * * * \\
(-6.766)\end{array}$ & & $\begin{array}{l}0.3791 * * * \\
(3.489)\end{array}$ \\
\hline$G D P G$ & $\begin{array}{l}-0.0145 \\
(-0.2083)\end{array}$ & & $\begin{array}{l}-46.001 \\
(-0.3146)\end{array}$ & $\begin{array}{l}-0.1011 \\
(-0.9349)\end{array}$ & & $\begin{array}{l}0.0047 \\
(0.8651)\end{array}$ & $\begin{array}{l}-0.1721 \\
(-1.306)\end{array}$ & & $\begin{array}{l}0.0049 \\
(0.3308)\end{array}$ & $\begin{array}{l}0.2209 \\
(1.231)\end{array}$ & & $\begin{array}{l}0.0012 \\
(0.4292)\end{array}$ \\
\hline$I B A$ & $\begin{array}{l}0.0256^{* * * *} \\
(2.875)\end{array}$ & & & $\begin{array}{l}0.0314 * * * \\
(5.523)\end{array}$ & & & $\begin{array}{l}0.0277^{*} \\
(1.808)\end{array}$ & & & $\begin{array}{l}-0.0229 \\
(-1.577)\end{array}$ & & \\
\hline ZROE & $\begin{array}{l}0.0006 * * * \\
(5.148)\end{array}$ & $\begin{array}{l}-6.1 \mathrm{E}-06^{* *} \\
(-2.571)\end{array}$ & & & & & & & & & & \\
\hline SDROE & & & & $\begin{array}{l}-18.03 * * * \\
(-11.049)\end{array}$ & $\begin{array}{l}0.2131 * * \\
(2.059)\end{array}$ & & & & & & & \\
\hline$R O E$ & & & & & & & $\begin{array}{l}-3.869 * * * \\
(-2.23)\end{array}$ & $\begin{array}{l}0.2055^{* *} \\
(2.044)\end{array}$ & & & & \\
\hline$R O A$ & & & & & & & & & & $\begin{array}{l}-128.9 * * * \\
(-6.616)\end{array}$ & $\begin{array}{l}-0.947 * * * \\
(-3.405)\end{array}$ & \\
\hline EQTA & & $\begin{array}{l}\mathbf{0 . 0 0 6 7} * * * \\
(4.898)\end{array}$ & $\begin{array}{l}\text { 666.18**** } \\
(3.819)\end{array}$ & & $\begin{array}{l}\mathbf{0 . 0 0 6 1} \text { **** } \\
(5.004)\end{array}$ & $\begin{array}{l}-\mathbf{0 . 0 1 9} \text { **** } \\
(-3.793)\end{array}$ & & $\begin{array}{l}\mathbf{0 . 0 2 3 5} \text { **** } \\
(3.457)\end{array}$ & $\begin{array}{l}-\mathbf{0 . 1 0 8} * * * \\
(-8.607)\end{array}$ & & $\begin{array}{l}-0.00069 \\
(-0.6933)\end{array}$ & $\begin{array}{l}-\mathbf{0 . 0 2 3} * * * * \\
(-7.784)\end{array}$ \\
\hline CFIVE & & $\begin{array}{l}0.0044 * \\
(1.826)\end{array}$ & & & $\begin{array}{l}0.0048 \\
(0.6973)\end{array}$ & & & $\begin{array}{l}-0.0082 \\
(-0.6351)\end{array}$ & & & $\begin{array}{l}0.0193 * * * \\
(5.439)\end{array}$ & \\
\hline$M P O W$ & & $\begin{array}{l}-0.0177 * * * \\
(-8.029)\end{array}$ & & & $\begin{array}{l}0.0152 * * * \\
(-4.449)\end{array}$ & & & $\begin{array}{l}0.0028 \\
(0.9486)\end{array}$ & & & $\begin{array}{l}-0.008^{* * *} \\
(-4.117)\end{array}$ & \\
\hline OVERHEAD & & $\begin{array}{l}-0.0147 \\
(-0.5291)\end{array}$ & & & $\begin{array}{l}-0.1013 \\
(-1.251)\end{array}$ & & & $\begin{array}{l}-0.0932 * * \\
(-2.242)\end{array}$ & & & $\begin{array}{l}-0.187 * * * \\
(-4.849)\end{array}$ & \\
\hline
\end{tabular}




\begin{tabular}{|c|c|c|c|c|c|c|c|c|c|c|c|c|}
\hline \multicolumn{13}{|l|}{ Continued } \\
\hline$L D R$ & & $\begin{array}{l}-0.0003 * * * \\
(-5.618)\end{array}$ & & & $\begin{array}{l}-0.001 * * * \\
(-3.385)\end{array}$ & & & $\begin{array}{l}-4 \mathrm{E}-04 * * * \\
(-2.643)\end{array}$ & & & $\begin{array}{l}-0.001 * * * \\
(-7.327)\end{array}$ & \\
\hline$L O A N$ & $\begin{array}{l}-0.329 * * * \\
(-8.618)\end{array}$ & & $\begin{array}{l}184.85 \text { *** } \\
(2.771)\end{array}$ & $\begin{array}{l}-0.307 * * * \\
(-8.373)\end{array}$ & & $\begin{array}{l}-0.012 * * * \\
(-5.426)\end{array}$ & $\begin{array}{l}-0.167 * * * \\
(-3.919)\end{array}$ & & $\begin{array}{l}-0.023 * * * \\
(-4.694)\end{array}$ & $\begin{array}{l}0.0667 \\
(0.8693)\end{array}$ & & $\begin{array}{l}-0.006 * * * \\
(-5.767) \\
-\end{array}$ \\
\hline$L L P$ & & & $\begin{array}{l}-63.815 \\
(-0.9593)\end{array}$ & & & $\begin{array}{l}0.0109 * * * \\
(5.56)\end{array}$ & & & $\begin{array}{l}0.0135 * * \\
(2.567)\end{array}$ & & & $\begin{array}{l}0.0047 * * * \\
(-3.754)\end{array}$ \\
\hline$D T A$ & & & $\begin{array}{l}22.966 \\
(0.4981)\end{array}$ & & & $\begin{array}{l}0.0056^{* * * *} \\
(3.227)\end{array}$ & & & $\begin{array}{l}0.0347 * * * \\
(-9.231)\end{array}$ & & & $\begin{array}{l}0.0075 * * * \\
(-9.462)\end{array}$ \\
\hline$S O B$ & $\begin{array}{l}0.7196^{* * * *} \\
(6.673)\end{array}$ & $\begin{array}{l}-0.0024 \\
(-1.55)\end{array}$ & $\begin{array}{l}-36.781 \\
(-0.3597)\end{array}$ & $\begin{array}{l}2.285 * * * \\
(19.088)\end{array}$ & $\begin{array}{l}-0.0058 * \\
(-1.823)\end{array}$ & $\begin{array}{l}0.0218 * * * \\
(6.336)\end{array}$ & $\begin{array}{l}0.9137 * * * \\
(14.484)\end{array}$ & $\begin{array}{l}-0.0035 \\
(-0.7009)\end{array}$ & $\begin{array}{l}0.0732 * * * \\
(9.513)\end{array}$ & $\begin{array}{l}1.117 * * * \\
(14.031)\end{array}$ & $\begin{array}{l}0.0083 * * * \\
(-5.386)\end{array}$ & $\begin{array}{l}0.0142 * * * \\
(8.394)\end{array}$ \\
\hline$P O B$ & $\begin{array}{l}0.4569 * * * \\
(4.916)\end{array}$ & $\begin{array}{l}-0.0011 \\
(-0.6564)\end{array}$ & $\begin{array}{l}52.434 \\
(0.5801)\end{array}$ & $\begin{array}{l}1.795 * * * \\
(19.027)\end{array}$ & $\begin{array}{l}-0.0037 \\
(-0.9919)\end{array}$ & $\begin{array}{l}0.016^{* * * *} \\
(5.291)\end{array}$ & $\begin{array}{l}0.6817 * * * \\
(13.716)\end{array}$ & $\begin{array}{l}0.0008 \\
(0.1413)\end{array}$ & $\begin{array}{l}0.0636 \text { *** } \\
(9.362)\end{array}$ & $\begin{array}{l}0.8083 * * * \\
(12.132)\end{array}$ & $\begin{array}{l}0.0066 \text { *** } \\
(-4.326)\end{array}$ & $\begin{array}{l}0.0137 * * * \\
(8.692)\end{array}$ \\
\hline$J V B$ & $\begin{array}{l}0.5999 * * * \\
(6.563)\end{array}$ & $\begin{array}{l}-0.0023 \\
(-1.541)\end{array}$ & $\begin{array}{l}-46.611 \\
(-0.4712)\end{array}$ & $\begin{array}{l}1.955 * * * \\
(19.757)\end{array}$ & $\begin{array}{l}-0.0053 \\
(-1.569) \\
-\end{array}$ & $\begin{array}{l}0.0194 * * * \\
(5.891)\end{array}$ & $\begin{array}{l}0.8119 * * * \\
(15.939)\end{array}$ & $\begin{array}{l}-0.0025 \\
(-0.4943)\end{array}$ & $\begin{array}{l}0.0683 * * * \\
(9.12)\end{array}$ & $\begin{array}{l}1.056^{* * *} \\
(13.289)\end{array}$ & $\begin{array}{l}0.0073 * * * \\
(-4.871) \\
-\end{array}$ & $\begin{array}{l}0.0153 * * * \\
(8.802)\end{array}$ \\
\hline$F O B$ & $\begin{array}{l}0.5381 * * * \\
(6.641) \\
\end{array}$ & $\begin{array}{l}-0.0024 * \\
(-1.67) \\
\end{array}$ & $\begin{array}{l}-36.781 \\
(-1.454) \\
\end{array}$ & $\begin{array}{l}2.262 * * * \\
(17.789) \\
\end{array}$ & $\begin{array}{l}0.0087 * * * \\
(-3.869) \\
\end{array}$ & $\begin{array}{l}0.0389 * * * \\
(14.058) \\
\end{array}$ & $\begin{array}{l}0.7077 * * * \\
(12.704) \\
\end{array}$ & $\begin{array}{l}-0.0013 \\
(-0.2849) \\
\end{array}$ & $\begin{array}{l}0.0902 * * * \\
(12.73) \\
\end{array}$ & $\begin{array}{l}0.8577 * * * \\
(11.01) \\
\end{array}$ & $\begin{array}{l}0.0075 * * * \\
(-4.891) \\
\end{array}$ & $\begin{array}{l}0.011 * * * \\
(8.539) \\
\end{array}$ \\
\hline $\begin{array}{l}\text { J-Statistic } \\
\mathrm{N}\end{array}$ & $\begin{array}{l}0.0072 \\
3488 \\
\end{array}$ & $\begin{array}{l}0.0072 \\
3488 \\
\end{array}$ & $\begin{array}{l}0.0072 \\
3488 \\
\end{array}$ & $\begin{array}{l}0.0102 \\
3488\end{array}$ & $\begin{array}{l}0.0102 \\
3488\end{array}$ & $\begin{array}{l}0.0102 \\
3488 \\
\end{array}$ & $\begin{array}{l}0.0034 \\
3906\end{array}$ & $\begin{array}{l}0.0034 \\
3906\end{array}$ & $\begin{array}{l}0.0034 \\
3906\end{array}$ & $\begin{array}{l}0.0075 \\
3906\end{array}$ & $\begin{array}{l}0.0075 \\
3906\end{array}$ & $\begin{array}{l}0.0075 \\
3906\end{array}$ \\
\hline
\end{tabular}


Table 4. Regression outputs with PERSON as the measure of the cost of intermediation

The models are estimated using Generalized Method of Moments (GMM) in a simultaneous equations system with individual fixed effects. (***), (**) and (*) indicate significance at the $1 \%$, $5 \%$ and $10 \%$ levels, respectively. The $t$-statistics are reported in parentheses. Endogenous variables are capital ratio (EQTA), personnel expenses ratio $(P E R S O N)$, insolvency measure (ZROE), risk-taking measure (SDROE) and profitability measure (ROE and ROA). The bold fonts are introduced to assess Hypothesis 1: a higher capital ratio is associated with an increase in the cost of intermediation, but a decrease in risk and profitability. Regression 1 uses ZROE as the dependent variable in the PERFORM equation shown in (1), while Regressions 2, 3, and 4 respectively use SDROE, ROE, and ROA.

\begin{tabular}{|c|c|c|c|c|c|c|c|c|c|c|c|c|}
\hline & \multicolumn{3}{|c|}{ Regression 1} & \multicolumn{3}{|c|}{ Regression 2} & \multicolumn{3}{|c|}{ Regression 3} & \multicolumn{3}{|c|}{ Regression 4} \\
\hline Variables & $E Q T A$ & PERSON & $Z R O E$ & $E Q T A$ & PERSON & SDROE & $E Q T A$ & PERSON & $R O E$ & $E Q T A$ & PERSON & $R O A$ \\
\hline PERSON & $\begin{array}{l}1.132 \\
(0.9777)\end{array}$ & & $\begin{array}{l}-461.33 * * * \\
(-5.691)\end{array}$ & $\begin{array}{l}-0.0042 \\
(-0.0639)\end{array}$ & & $\begin{array}{l}0.0387 * * * \\
(12.344)\end{array}$ & $\begin{array}{l}-0.879 * * * \\
(-16.227)\end{array}$ & & $\begin{array}{l}0.1127 \text { *** } \\
(5.777)\end{array}$ & $\begin{array}{l}-0.805 * * * \\
(-6.335)\end{array}$ & & $\begin{array}{l}0.0138 * * * \\
(5.227)\end{array}$ \\
\hline SIZE & $\begin{array}{l}0.0232 \\
(0.2259)\end{array}$ & & & $\begin{array}{l}-0.129 * * * \\
(-16.187)\end{array}$ & & & $\begin{array}{l}-0.15 * * * \\
(-20.485)\end{array}$ & & & $\begin{array}{l}-0.109 * * * \\
(-7.377)\end{array}$ & & \\
\hline$G D P G$ & $\begin{array}{l}-0.2511 \\
(-0.475)\end{array}$ & & $\begin{array}{l}-34.859 \\
(-0.4877)\end{array}$ & $\begin{array}{l}-0.1426^{*} \\
(-1.874)\end{array}$ & & $\begin{array}{l}0.0031 * * \\
(2.429)\end{array}$ & $\begin{array}{l}-0.419 * * * \\
(-4.127)\end{array}$ & & $\begin{array}{l}0.0205 \\
(1.079)\end{array}$ & $\begin{array}{l}-0.1503 \\
(-1.622)\end{array}$ & & $\begin{array}{l}-0.0035 \\
(-0.8979)\end{array}$ \\
\hline$I B A$ & $\begin{array}{l}-0.0073 \\
(-0.897)\end{array}$ & & & $\begin{array}{l}0.00603 \\
(1.424)\end{array}$ & & & $\begin{array}{l}0.0133 * \\
(1.832)\end{array}$ & & & $\begin{array}{l}0.0153 * * \\
(2.085)\end{array}$ & & \\
\hline ZROE & $\begin{array}{l}0.0018 \\
(1.174)\end{array}$ & $\begin{array}{l}-0.0013 * * * \\
(-7.95)\end{array}$ & & & & & & & & & & \\
\hline SDROE & & & & $\begin{array}{l}-18.96 * * * \\
(-11.308)\end{array}$ & $\begin{array}{l}18.159 * * * \\
(4.285)\end{array}$ & & & & & & & \\
\hline$R O E$ & & & & & & & $\begin{array}{l}0.2505 \\
(0.2272)\end{array}$ & $\begin{array}{l}-13.82 * * * \\
(-10.679)\end{array}$ & & & & \\
\hline$R O A$ & & & & & & & & & & $\begin{array}{l}15.74 * \\
(1.693)\end{array}$ & $\begin{array}{l}-12.61 * \\
(-1.759)\end{array}$ & \\
\hline$E Q T A$ & & $\begin{array}{l}\mathbf{0 . 6 3 5 3} * * * \\
(5.761)\end{array}$ & $\begin{array}{l}\mathbf{5 1 8 . 4 9} * * * * \\
(4.714)\end{array}$ & & $\begin{array}{l}\mathbf{0 . 2 7 7 6} \text { **** } \\
(3.443)\end{array}$ & $\begin{array}{l}\mathbf{- 0 . 0 1 7 3} * * * \\
(-4.096)\end{array}$ & & $\begin{array}{l}\mathbf{- 0 . 0 1 0 9} \\
(-0.1386)\end{array}$ & $\begin{array}{l}-\mathbf{0 . 1 2 6} * * * \\
(-9.239)\end{array}$ & & $\begin{array}{l}\mathbf{0 . 3 9 5 4} * * * \\
(5.781)\end{array}$ & $\begin{array}{l}\mathbf{2 . 1 8}^{\mathbf{E}} \mathbf{- 0 5} \\
(0.008)\end{array}$ \\
\hline CFIVE & & $\begin{array}{l}0.5893 * * * \\
(5.714)\end{array}$ & & & $\begin{array}{l}0.4263 * * * \\
(3.191)\end{array}$ & & & $\begin{array}{l}2.577 * * * \\
(12.3)\end{array}$ & & & $\begin{array}{l}1.155^{* * *} \\
(7.869)\end{array}$ & \\
\hline$M P O W$ & & $\begin{array}{l}-1.286 * * * \\
(-5.769)\end{array}$ & & & $\begin{array}{l}-0.3822 * \\
(-1.748)\end{array}$ & & & $\begin{array}{l}-2.739 * * * \\
(-6.863)\end{array}$ & & & $\begin{array}{l}-2.725 * * * \\
(-8.984)\end{array}$ & \\
\hline OVERHEAD & & $\begin{array}{l}-0.3309 \\
(-0.7285)\end{array}$ & & & $\begin{array}{l}2.675^{*} \\
(1.888)\end{array}$ & & & $\begin{array}{l}-1.559 \\
(-0.7533)\end{array}$ & & & $\begin{array}{l}2.291 * * \\
(2.217)\end{array}$ & \\
\hline
\end{tabular}




\begin{tabular}{|c|c|c|c|c|c|c|c|c|c|c|c|c|}
\hline \multicolumn{13}{|l|}{ Continued } \\
\hline$\overline{L D R}$ & & $\begin{array}{l}-0.0019 \\
(-0.5202)\end{array}$ & & & $\begin{array}{l}-0.023 * * * \\
(-2.912)\end{array}$ & & & $\begin{array}{l}-0.0241^{* * *} \\
(-2.919)\end{array}$ & & & $\begin{array}{l}0.0128 * * * \\
(4.079)\end{array}$ & \\
\hline$L O A N$ & $\begin{array}{l}0.049 \\
(0.1586)\end{array}$ & & $\begin{array}{l}71.876^{* *} \\
(1.982)\end{array}$ & $\begin{array}{l}-0.103 * * * \\
(-5.684)\end{array}$ & & $\begin{array}{l}-0.0061 * * * \\
(-6.337)\end{array}$ & $\begin{array}{l}-0.0044 \\
(-0.2422)\end{array}$ & & $\begin{array}{l}-0.025 * * * \\
(-7.277)\end{array}$ & $\begin{array}{l}0.1087 * * \\
(2.469)\end{array}$ & & $\begin{array}{l}-0.005^{* * * *} \\
(-4.961)\end{array}$ \\
\hline$L L P$ & & & $\begin{array}{l}56.557 \\
(1.212)\end{array}$ & & & $\begin{array}{l}0.0017^{* *} \\
(2.358)\end{array}$ & & & $\begin{array}{l}0.0348 * * * \\
(-3.339)\end{array}$ & & & $\begin{array}{l}0.0012 \\
(0.4708)\end{array}$ \\
\hline$D T A$ & & & $\begin{array}{l}47.484 * * \\
(2.196)\end{array}$ & & & $\begin{array}{l}0.0015 \\
(0.9817)\end{array}$ & & & $\begin{array}{l}0.0698 * * * \\
(-8.192)\end{array}$ & & & $\begin{array}{l}-0.0076 * * * \\
(-6.559)\end{array}$ \\
\hline$S O B$ & $\begin{array}{l}-1.076 \\
(-0.438)\end{array}$ & $\begin{array}{l}0.3221 * * * \\
(5.403)\end{array}$ & $\begin{array}{l}244.59 * * * \\
(6.563)\end{array}$ & $\begin{array}{l}2.782 * * * \\
(18.213)\end{array}$ & $\begin{array}{l}-0.162 * * * \\
(-2.692)\end{array}$ & $\begin{array}{l}0.0054 * * * \\
(3.275)\end{array}$ & $\begin{array}{l}3.159 * * * \\
(24.583)\end{array}$ & $\begin{array}{l}-0.655^{* * * *} \\
(-6.228)\end{array}$ & $\begin{array}{l}0.0548^{* * * *} \\
(12.91)\end{array}$ & $\begin{array}{l}2.291 * * * \\
(7.562)\end{array}$ & $\begin{array}{l}-0.1794 * \\
(-1.706)\end{array}$ & $\begin{array}{l}0.0043 * * * \\
(6.442)\end{array}$ \\
\hline$P O B$ & $\begin{array}{l}-1.118 \\
(-0.523)\end{array}$ & $\begin{array}{l}0.3233 * * * \\
(5.097)\end{array}$ & $\begin{array}{l}294.27 * * * \\
(7.644)\end{array}$ & $\begin{array}{l}2.235^{* * *} \\
(18.227)\end{array}$ & $\begin{array}{l}-0.0844 \\
(-1.396)\end{array}$ & $\begin{array}{l}0.0011 \\
(0.7112)\end{array}$ & $\begin{array}{l}2.607 * * * \\
(24.835)\end{array}$ & $\begin{array}{l}-0.868 * * * \\
(-8.401)\end{array}$ & $\begin{array}{l}0.052 * * * \\
(12.781)\end{array}$ & $\begin{array}{l}1.896^{* * *} \\
(7.643)\end{array}$ & $\begin{array}{l}-0.341 * * * \\
(-3.782)\end{array}$ & $\begin{array}{l}0.0046^{* * * *} \\
(6.41)\end{array}$ \\
\hline$J V B$ & $\begin{array}{l}-0.894 \\
(-0.439)\end{array}$ & $\begin{array}{l}0.1313^{* *} \\
(2.177)\end{array}$ & $\begin{array}{l}178.91 * * * \\
(5.219)\end{array}$ & $\begin{array}{l}2.397 * * * \\
(18.727)\end{array}$ & $\begin{array}{l}-0.203 * * * \\
(-3.579)\end{array}$ & $\begin{array}{l}0.0063^{* * *} \\
(3.828)\end{array}$ & $\begin{array}{l}2.716^{* * *} \\
(25.451)\end{array}$ & $\begin{array}{l}-0.963 * * * \\
(-9.604)\end{array}$ & $\begin{array}{l}0.0593 * * * \\
(13.534)\end{array}$ & $\begin{array}{l}1.957 * * * \\
(7.496)\end{array}$ & $\begin{array}{l}-0.435 * * * \\
(-5.236)\end{array}$ & $\begin{array}{l}0.0057 * * * \\
(7.456)\end{array}$ \\
\hline$F O B$ & $\begin{array}{l}-0.8689 \\
(-0.413)\end{array}$ & $\begin{array}{l}0.1153 * * \\
(2.065)\end{array}$ & $\begin{array}{l}157.29 * * * \\
(4.893)\end{array}$ & $\begin{array}{l}2.762 * * * \\
(17.611)\end{array}$ & $\begin{array}{l}-0.429 * * * \\
(-6.581)\end{array}$ & $\begin{array}{l}0.0204 * * * \\
(13.19)\end{array}$ & $\begin{array}{l}2.679 * * * \\
(26.303)\end{array}$ & $\begin{array}{l}-0.2592 * * \\
(-2.502)\end{array}$ & $\begin{array}{l}0.0704 * * * \\
(15.696)\end{array}$ & $\begin{array}{l}1.983^{* * *} * \\
(7.062)\end{array}$ & $\begin{array}{l}-0.277 * * * \\
(-3.376)\end{array}$ & $\begin{array}{l}0.0039 * * * \\
(6.851)\end{array}$ \\
\hline $\begin{array}{l}\text { J-Statistic } \\
\mathrm{N}\end{array}$ & $\begin{array}{r}0.00203 \\
3528\end{array}$ & $\begin{array}{r}0.00203 \\
3528\end{array}$ & $\begin{array}{r}0.00203 \\
3528\end{array}$ & $\begin{array}{r}0.0039 \\
3528\end{array}$ & $\begin{array}{r}0.0039 \\
3528\end{array}$ & $\begin{array}{r}0.0039 \\
3528\end{array}$ & $\begin{array}{r}0.0146 \\
3873\end{array}$ & $\begin{array}{r}0.0146 \\
3873\end{array}$ & $\begin{array}{r}0.0146 \\
3873\end{array}$ & $\begin{array}{r}0.0095 \\
4001\end{array}$ & $\begin{array}{r}0.0095 \\
4001\end{array}$ & $\begin{array}{r}0.0095 \\
4001\end{array}$ \\
\hline
\end{tabular}


Table 5. Regression outputs to analyze the influence of banks ownership type when RNIM is used as the measure of the cost of intermediation

The models are estimated using Generalized Method of Moments (GMM) in a simultaneous equations system with individual fixed effects. $(* * *),(* *)$ and $(*)$ indicate significance at the $1 \%$, $5 \%$ and $10 \%$ levels, respectively. The $t$-statistics are reported in parentheses. Endogenous variables are capital ratio (EQTA), the profitability-adjusted net interest margin (RNIM), insolvency measure (ZROE), risk-taking measure (SDROE) and profitability (ROE and ROA). The bold fonts are introduced to assess Hypothesis 2: There is a different impact of a higher capital ratio on the cost of intermediation, risk and profitability among banks with a different ownership type. Regression 1 uses ZROE as the dependent variable in the PERFORM equation shown in System (1), while Regressions 2, 3, and 4 respectively use SDROE, ROE, and $R O A$.

\begin{tabular}{|c|c|c|c|c|c|c|c|c|c|c|c|c|}
\hline \multirow[b]{2}{*}{ Variables } & \multicolumn{3}{|c|}{ Regression 1} & \multicolumn{3}{|c|}{ Regression 2} & \multicolumn{3}{|c|}{ Regression 3} & \multicolumn{3}{|c|}{ Regression 4} \\
\hline & EQTA & RNIM & ZROE & EQTA & RNIM & SDROE & EQTA & RNIM & $R O E$ & EQTA & RNIM & $R O A$ \\
\hline RNIM & $\begin{array}{l}40.051 * * * \\
(3.949)\end{array}$ & & $\begin{array}{l}14323.63 \\
(0.7045)\end{array}$ & $\begin{array}{l}20.549 * \\
(1.679)\end{array}$ & & $\begin{array}{l}-0.6759 \\
(-0.7349)\end{array}$ & $\begin{array}{l}41.852 * * * \\
(4.429)\end{array}$ & & $\begin{array}{l}3.839 * * \\
(2.442)\end{array}$ & $\begin{array}{l}40.602 * * * \\
(4.088)\end{array}$ & & $\begin{array}{l}0.0917 \\
(0.3561)\end{array}$ \\
\hline SIZE & $\begin{array}{l}-0.0323 * * \\
(-2.151)\end{array}$ & & & $\begin{array}{l}-0.097 * * * \\
(-5.343)\end{array}$ & & & $\begin{array}{l}-0.0412 * * \\
(-2.537)\end{array}$ & & & $\begin{array}{l}-0.0220 \\
(-1.065)\end{array}$ & & \\
\hline$G D P G$ & $\begin{array}{l}-0.0599 \\
(-0.4350)\end{array}$ & & $\begin{array}{l}0.8819 \\
(0.0041)\end{array}$ & $\begin{array}{l}-0.0528 \\
(-0.4172)\end{array}$ & & $\begin{array}{l}0.00047 \\
(0.0491)\end{array}$ & $\begin{array}{l}-0.2851 * * \\
(-1.978)\end{array}$ & & $\begin{array}{l}-0.0119 \\
(-0.6819)\end{array}$ & $\begin{array}{l}-0.192 \\
(-1.569)\end{array}$ & & $\begin{array}{l}-0.0036 \\
(-1.141)\end{array}$ \\
\hline$I B A$ & $\begin{array}{l}0.0106 \\
(0.8273)\end{array}$ & & & $\begin{array}{l}0.0133 \\
(1.393)\end{array}$ & & & $\begin{array}{l}0.0538 * * * \\
(3.591)\end{array}$ & & & $\begin{array}{l}0.0337 * * * \\
(2.753)\end{array}$ & & \\
\hline ZROE & $\begin{array}{l}0.0012 * * * \\
(4.759)\end{array}$ & $\begin{array}{l}-3.5 \mathrm{E}-05^{* * *} \\
(-3.505)\end{array}$ & & & & & & & & & & \\
\hline SDROE & & & & $\begin{array}{l}-18.31 * * * \\
(-5.319)\end{array}$ & $\begin{array}{l}0.0473 \\
(0.1939)\end{array}$ & & & & & & & \\
\hline$R O E$ & & & & & & & $\begin{array}{l}0.5889 \\
(0.2428)\end{array}$ & $\begin{array}{l}0.1779 * * * \\
(2.737)\end{array}$ & & & & \\
\hline$R O A$ & & & & & & & & & & $\begin{array}{l}-17.119 \\
(-1.264)\end{array}$ & $\begin{array}{l}0.6319 * * \\
(2.384)\end{array}$ & \\
\hline$E Q T A * S O B$ & & $\begin{array}{l}0.1164 \\
(0.6522)\end{array}$ & $\begin{array}{l}5373.82 \\
(0.9837)\end{array}$ & & $\begin{array}{l}0.2814 \\
(0.9949)\end{array}$ & $\begin{array}{l}0.0517 \\
(0.2048)\end{array}$ & & $\begin{array}{l}0.1893 * * \\
(2.013)\end{array}$ & $\begin{array}{l}-0.1647 \\
(-0.4468)\end{array}$ & & $\begin{array}{l}0.3255^{* *} \\
(2.435)\end{array}$ & $\begin{array}{l}-0.0159 \\
(-0.3138)\end{array}$ \\
\hline$E Q T A * P O B$ & & $\begin{array}{l}0.0148 * * \\
(2.387)\end{array}$ & $\begin{array}{l}4843.47 * * * \\
(3.576)\end{array}$ & & $\begin{array}{l}0.0017 \\
(0.1186)\end{array}$ & $\begin{array}{l}-0.174 * * * \\
(-2.608)\end{array}$ & & $\begin{array}{l}-0.00301 \\
(-0.6910)\end{array}$ & $\begin{array}{l}-0.1934 * \\
(-1.668)\end{array}$ & & $\begin{array}{l}0.0076 \\
(1.456)\end{array}$ & $\begin{array}{l}-0.053 * * * \\
(-2.919)\end{array}$ \\
\hline$E Q T A * J V B$ & & $\begin{array}{l}0.0199 * * * \\
(3.285)\end{array}$ & $\begin{array}{l}-1087.63 * * \\
(-2.103)\end{array}$ & & $\begin{array}{l}0.0054 \\
(0.3285)\end{array}$ & $\begin{array}{l}0.0849 * * * \\
(2.819)\end{array}$ & & $\begin{array}{l}0.0222 * * * \\
(4.416)\end{array}$ & $\begin{array}{l}-0.0901 * \\
(-1.947)\end{array}$ & & $\begin{array}{l}0.0157 \text { *** } \\
(3.767)\end{array}$ & $\begin{array}{l}-0.0025 \\
(-0.2835)\end{array}$ \\
\hline$E Q T A * F O B$ & & $\begin{array}{l}-0.1453 \\
(-0.7854)\end{array}$ & $\begin{array}{l}-27947 * * \\
(-1.963)\end{array}$ & & $\begin{array}{l}0.1401 \\
(0.2728)\end{array}$ & $\begin{array}{l}0.9369 \\
(1.442)\end{array}$ & & $\begin{array}{l}0.1834 \\
(1.568)\end{array}$ & $\begin{array}{l}1.076 \\
(1.085)\end{array}$ & & $\begin{array}{l}0.2599 \\
(1.683)\end{array}$ & $\begin{array}{l}0.3936 * * \\
(2.509)\end{array}$ \\
\hline
\end{tabular}




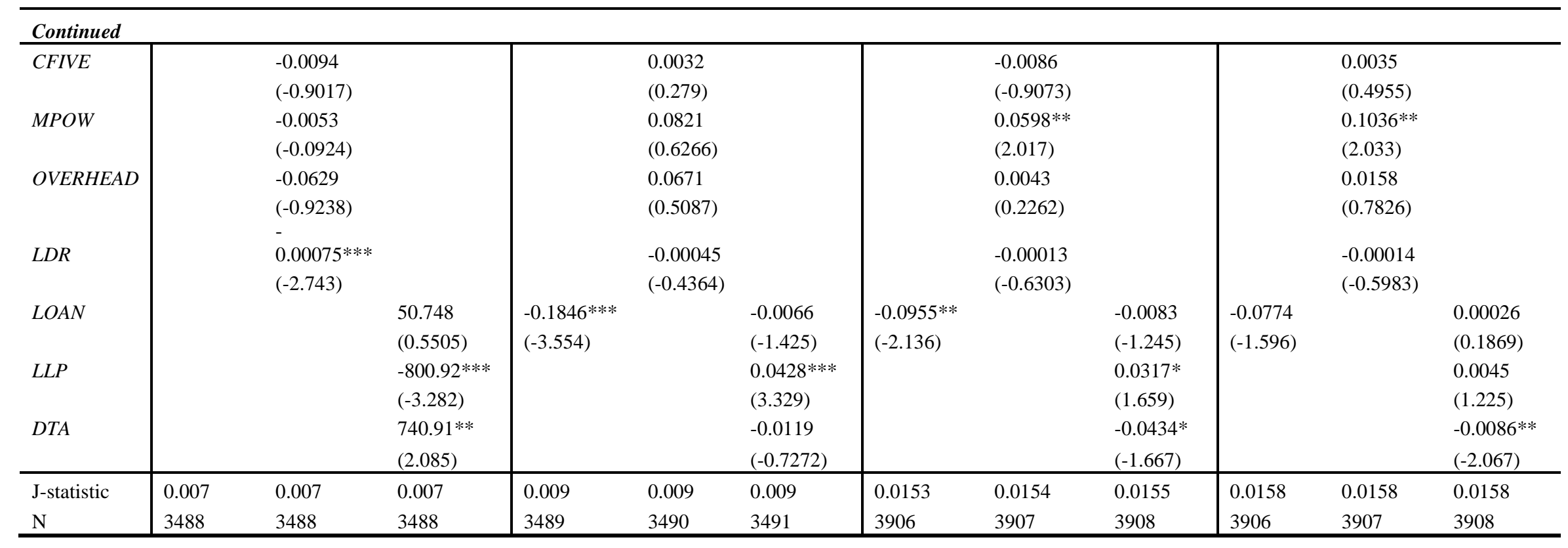


Table 6. Regression outputs to analyze the influence of banks ownership type with PERSON as the measure of the cost of intermediation

The models are estimated using Generalized Method of Moments (GMM) in a simultaneous equations system with individual fixed effects. (***), (**) and (*) indicate significance at the $1 \%$, $5 \%$ and $10 \%$ levels, respectively. The t-statistics are reported in parentheses. Endogenous variables are capital ratio (EQTA), the personnel expenses ratio (PERSON), insolvency measure $(Z R O E)$, risk-taking measure (SDROE) and profitability (ROE and ROA). The bold fonts are introduced to assess Hypothesis 2: There is a different impact of a higher capital ratio on the cost of intermediation, risk and profitability among banks with a different ownership type. Regression 1 uses ZROE as the dependent variable in the PERFORM equation shown in System (1), while Regressions 2, 3, and 4 respectively use SDROE, ROE, and $R O A$

\begin{tabular}{|c|c|c|c|c|c|c|c|c|c|c|c|c|}
\hline & \multicolumn{3}{|c|}{ Regression 1} & \multicolumn{3}{|c|}{ Regression 2} & \multicolumn{3}{|c|}{ Regression 3} & \multicolumn{3}{|c|}{ Regression 4} \\
\hline Variables & $E Q T A$ & PERSON & $\overline{Z R O E}$ & $E Q T A$ & PERSON & SDROE & $E Q T A$ & PERSON & $R O E$ & $E Q T A$ & PERSON & $R O A$ \\
\hline PERSON & $\begin{array}{l}2.148 \\
(1.018)\end{array}$ & & $\begin{array}{l}-288.35 \\
(-1.458)\end{array}$ & $\begin{array}{l}-0.1982 \\
(-0.5128)\end{array}$ & & $\begin{array}{l}0.0417 \text { *** } \\
(5.127)\end{array}$ & $\begin{array}{l}-1.191 * * * \\
(-4.454)\end{array}$ & & $\begin{array}{l}0.0809^{* *} \\
(2.107)\end{array}$ & $\begin{array}{l}-0.4877 * * \\
(-2.279)\end{array}$ & & $\begin{array}{l}0.0205^{* * *} \\
(3.511)\end{array}$ \\
\hline SIZE & $\begin{array}{l}0.1331 \\
(0.7324)\end{array}$ & & & $\begin{array}{l}-0.124 * * * \\
(-5.6)\end{array}$ & & & $\begin{array}{l}-0.148 * * * \\
(-7.987)\end{array}$ & & & $\begin{array}{l}-0.0453 * * \\
(-2.138)\end{array}$ & & \\
\hline$G D P G$ & $\begin{array}{l}0.7577 \\
(0.9388)\end{array}$ & & $\begin{array}{l}-156.85 \\
(-0.8062)\end{array}$ & $\begin{array}{l}-0.1931 * \\
(-1.794)\end{array}$ & & $\begin{array}{l}-0.00018 \\
(-0.0381)\end{array}$ & $\begin{array}{l}-0.3129 * * \\
(-2.238)\end{array}$ & & $\begin{array}{l}0.0174 \\
(0.8102)\end{array}$ & $\begin{array}{l}-0.051 \\
(-0.3773)\end{array}$ & & \\
\hline$I B A$ & $\begin{array}{l}0.0110 \\
(0.3956)\end{array}$ & & & $\begin{array}{l}-0.0035 \\
(-0.3277)\end{array}$ & & & $\begin{array}{l}-0.012 \\
(-0.608)\end{array}$ & & & $\begin{array}{l}0.0122 \\
(1.594)\end{array}$ & & \\
\hline ZROE & $\begin{array}{l}0.0035^{*} \\
(1.918)\end{array}$ & $\begin{array}{l}0.0014 \\
(0.8333)\end{array}$ & & & & & & & & & & \\
\hline SDROE & & & & $\begin{array}{l}-20.23 * * * \\
(-4.882)\end{array}$ & $\begin{array}{l}30.946 * * * \\
(3.385)\end{array}$ & & & & & & & \\
\hline$R O E$ & & & & & & & $\begin{array}{l}-1.605 \\
(-0.5773)\end{array}$ & $\begin{array}{l}-6.983 \\
(-1.495)\end{array}$ & & & & \\
\hline$R O A$ & & & & & & & & & & $\begin{array}{l}27.744 * * * \\
(6.159)\end{array}$ & $\begin{array}{l}40.698 \\
(1.177)\end{array}$ & \\
\hline$E Q T A * S O B$ & & $\begin{array}{l}25.326 \\
(1.479)\end{array}$ & $\begin{array}{l}2326.72 \\
(0.9512)\end{array}$ & & $\begin{array}{l}2.187 \\
(0.3461)\end{array}$ & $\begin{array}{l}0.296503 \\
(1.987)\end{array}$ & & $\begin{array}{l}21.945 * * \\
(2.557)\end{array}$ & $\begin{array}{l}-0.1108 \\
(-0.4317)\end{array}$ & & $\begin{array}{l}2.586 \\
(0.1324)\end{array}$ & $\begin{array}{l}-0.0426 \\
(-0.7131)\end{array}$ \\
\hline$E Q T A * P O B$ & & $\begin{array}{l}0.8407 \\
(1.443)\end{array}$ & $\begin{array}{l}727.9 * \\
(1.601)\end{array}$ & & $\begin{array}{l}0.2858 \\
(1.055)\end{array}$ & $\begin{array}{l}0.0428 \\
(1.613)\end{array}$ & & $\begin{array}{l}0.6462 * * \\
(2.433)\end{array}$ & $\begin{array}{l}-0.1667 * * \\
(-2.041)\end{array}$ & & $\begin{array}{l}-0.6655 \\
(-0.8951)\end{array}$ & $\begin{array}{l}0.0183 \\
(1.448)\end{array}$ \\
\hline$E Q T A * J V B$ & & $\begin{array}{l}-2.749 * \\
(-1.745)\end{array}$ & $\begin{array}{l}334.83 \\
(0.7815)\end{array}$ & & $\begin{array}{l}0.1735 \\
(0.3061)\end{array}$ & $\begin{array}{l}-0.0256 \\
(-1.111)\end{array}$ & & $\begin{array}{l}-1.741 * * * \\
(-3.627)\end{array}$ & $\begin{array}{l}-0.1705^{*} \\
(-1.867)\end{array}$ & & $\begin{array}{l}-2.25 * * * \\
(-2.668)\end{array}$ & $\begin{array}{c}-0.0013 \\
(-0.0788)\end{array}$ \\
\hline$E Q T A * F O B$ & & $\begin{array}{l}72.545^{* *} \\
(2.216)\end{array}$ & $\begin{array}{l}-2848.06 \\
(-0.6052)\end{array}$ & & $\begin{array}{l}-9.579 \\
(-0.7332)\end{array}$ & $\begin{array}{l}-0.6889 * * \\
(-1.972)\end{array}$ & & $\begin{array}{l}30.447 * * * \\
(2.665)\end{array}$ & $\begin{array}{l}1.782 * * \\
(2.371)\end{array}$ & & $\begin{array}{l}31.554 * * \\
(1.978)\end{array}$ & $\begin{array}{l}0.0898 \\
(0.9294)\end{array}$ \\
\hline
\end{tabular}




\begin{tabular}{|c|c|c|c|c|c|c|c|c|c|c|c|c|}
\hline \multicolumn{13}{|l|}{ Continued } \\
\hline CFIVE & & $\begin{array}{l}-0.3752 \\
(-0.4129)\end{array}$ & & & $\begin{array}{l}0.0538 \\
(0.1301)\end{array}$ & & & $\begin{array}{l}0.8102 \\
(0.9519)\end{array}$ & & & $\begin{array}{l}-0.5896 \\
(-0.4991)\end{array}$ & \\
\hline$M P O W$ & & $\begin{array}{l}13.758 * \\
(1.889)\end{array}$ & & & $\begin{array}{l}0.3163 \\
(0.1264)\end{array}$ & & & $\begin{array}{l}6.071 * * \\
(2.163)\end{array}$ & & & $\begin{array}{l}3.134 \\
(0.5377)\end{array}$ & \\
\hline OVERHEAD & & $\begin{array}{l}6.999 \\
(1.345)\end{array}$ & & & $\begin{array}{l}-1.308 \\
(-0.5727\end{array}$ & & & $\begin{array}{l}0.9428 \\
(0.4039)\end{array}$ & & & $\begin{array}{l}2.921 \\
(1.391)\end{array}$ & \\
\hline$L D R$ & & $\begin{array}{l}0.0845^{*} \\
(1.816)\end{array}$ & & & $\begin{array}{l}-0.0709 * \\
(-2.042)\end{array}$ & & & $\begin{array}{l}0.0338 * \\
(1.709)\end{array}$ & & & $\begin{array}{l}0.0338 \\
(1.589)\end{array}$ & \\
\hline$L O A N$ & $\begin{array}{l}-0.4409 \\
(-1.319)\end{array}$ & & $\begin{array}{l}91.089 \\
(1.427)\end{array}$ & $\begin{array}{l}-0.1035 \\
(-1.518)\end{array}$ & & $\begin{array}{l}-0.011 * * * \\
(-2.897)\end{array}$ & $\begin{array}{l}0.0287 \\
(0.5372)\end{array}$ & & $\begin{array}{l}-0.0142 * \\
(-1.733)\end{array}$ & $\begin{array}{l}0.0299 \\
(0.5501)\end{array}$ & & $\begin{array}{l}-0.0018 \\
(-1.257)\end{array}$ \\
\hline$L L P$ & & & $\begin{array}{l}-61.212 \\
(-0.3688)\end{array}$ & & & $\begin{array}{l}-0.0138 \\
(-1.558)\end{array}$ & & & $\begin{array}{l}-0.0124 \\
(-0.349)\end{array}$ & & & $\begin{array}{l}-0.0045 \\
(-0.9243)\end{array}$ \\
\hline$D T A$ & & & $\begin{array}{l}85.286 \\
(0.7481)\end{array}$ & & & $\begin{array}{l}0.0191 * * * \\
(2.855)\end{array}$ & & & $\begin{array}{l}-0.088 * * * \\
(-5.767)\end{array}$ & & & $\begin{array}{l}-0.0066 * * \\
(-2.337)\end{array}$ \\
\hline J-statistic & 0.00071 & 0.00071 & 0.00071 & 0.0052 & 0.0052 & 0.0052 & 0.0122 & 0.0122 & 0.0122 & 0.0085 & 0.0085 & 0.0085 \\
\hline $\mathrm{N}$ & 3528 & 3528 & 3528 & 3528 & 3528 & 3528 & 3873 & 3873 & 3873 & 4001 & 4001 & 4001 \\
\hline
\end{tabular}

